Kapata Arkeologi, 13(1), 1-20

ISSN (cetak): 1858-4101

ISSN (elektronik): 2503-0876

http://kapata-arkeologi.kemdikbud.go.id

\title{
STRUKTUR SOSIAL PADA RUMAH PEJABAT TINGGI PERKEBUNAN ZAMAN HINDIA BELANDA DI JAWA BAGIAN BARAT
}

\section{The Social Structure on High Officials of Plantation Residence in the Dutch East Indies Period in West Part of Java}

\author{
Lia Nuralia \\ Balai Arkeologi Jawa Barat - Indonesia \\ Jl. Raya Cinunuk km.17, Cileunyi, Bandung \\ liabalar@yahoo.com
}

\begin{abstract}
Naskah diterima: 04/01/2017; direvisi: 22/03 - 06/06/2017; disetujui: 14/06/2017
Publikasi ejurnal: 25/07/2017
\end{abstract}

\begin{abstract}
This paper aims to reveal the social structure on the high officials of plantation residence in west part of Java. This paper is based on research reports using archaeological research methods, explaining about the architecture, layout, materials, and technology used to determine the symbolic meaning behind the physical form of the building. Structure concept and non-verbal communication concept can explain that the high officials of plantation residence is a central building in the plantation emplacement. The residence as a symbol of great power, especially in the plantation environment that still exist until now.
\end{abstract}

Keywords: Social structure, The High Officials of Plantation Residence, west part of Java

\begin{abstract}
Abstrak
Tulisan ini bertujuan mengungkap struktur sosial pada rumah pejabat tinggi perkebunan peninggalan zaman Hindia Belanda di Jawa bagian barat. Tulisan ini berdasarkan laporan hasil penelitian yang menggunakan metode penelitian arkeologi, menjelaskan tentang arsitektur, tata letak, bahan, dan teknologi yang digunakan untuk mengetahui makna simbolik dibalik wujud fisik bangunan. Structure concept dan non-verbal communication concept dapat menjelaskan bahwa rumah pejabat tinggi perkebunan merupakan bangunan sentral dalam emplasemen perkebunan. Rumah tersebut sebagai simbol kuasa besar, terutama di lingkungan perkebunan yang masih eksis sampai sekarang.
\end{abstract}

Kata kunci: Struktur sosial, rumah pejabat tinggi perkebunan, Jawa bagian Barat

\section{PENDAHULUAN}

Struktur sosial dalam masyarakat perkebunan peninggalan zaman Pemerintahan Hindia Belanda menunjukkan identitas kolonial. Struktur sosial tampak dari artefak, simbol, dan ruang, yang masih menyimpan kekuasaan dan makna simbolik di balik wujud fisiknya. Apabila dikaitkan dengan identitas masyarakat masa lalu yang pernah tinggal di dalamnya, akan tergambar bentuk penggolongan masyarakat perkebunan dalam beberapa kelas sosial. Pada sekarang ini, pelapisan sosial yang terbagi dalam beberapa kelas sosial, dapat diungkap dari wujud fisik bangunan kolonial yang masih ada di lingkungan perkebunan, salah satunya pada rumah tinggal pejabat tinggi perkebunan.

Rumah tinggal pejabat tinggi perkebunan menjadi bangunan penting, berkaitan dengan orang yang tinggal didalamnya, sebagai pemilik dan pengelola utama perusahaan perkebunan besar dalam situasi kolonial. Sejarah mencatat bahwa pada abad ke-19-20 Masehi merupakan puncak kejayaan kolonialisme Belanda di Indonesia (Hindia Belanda), dengan pesatnya pendirian dan perkembangan perkebunanperkebunan besar. ${ }^{\text {i }}$ Keberadaan perkebunanpekebunan besar tersebut adalah aspek terpenting bagi negeri Belanda, karena surplus ekspor komoditi perkebunan telah berhasil 
mengisi kekosongan kas negara (O’Malley, 1988: 197). Setelah dikeluarkannya undangundang gula dan undang-undang agraria, ${ }^{\text {ii }}$ sebagian besar pemilik perusahaan perkebunan besar tersebut ketika itu adalah swasta asing Eropa dan Cina.

Para pemilik perusahaan biasanya membuka lahan perkebunan lebih dari satu, di lokasi sama dan atau berbeda. Mereka sering disebut tuan tanah (landheer), sekaligus sebagai pejabat tinggi dalam struktur perkebunan (administrateur). Pengelolaan dan pengawasan perusahaan sangat utama, sehingga para tuan tanah atau administratur membangun rumah tinggal dekat atau berada di lokasi kebun. Lokasi kebun terbagi menjadi dua wilayah, yaitu kebun yang ditanami tanaman-tanaman tertentu dan emplasemen permukiman tempat didirikannya bangunan fasilitas perusahaan.

Penelitian keberadaan bangunan kolonial perkebunan dengan arsitektur kolonial iii yang masih asli sangat minim, sehingga jejak sejarah industri perkebunan dikhawatirkan terabaikan, bahkan hilang tanpa ada satu usaha untuk merekam jejak-jejaknya. Jejak sejarah tersebut sangat penting dilestarikan untuk bahan pembelajaran dan pembentukan jati diri bangsa. Jejak sejarah industri perkebunan masa kolonial mengandung makna simbolik dibalik wujud fisiknya, salah satunya kebudayaan penjajah Belanda. Dalam kenyataannya kebudayaan penjajah ini telah menjadi kebiasaan yang dipraktekkan oleh bangsa Indonesia. Hal ini dapat dijadikan cermin, dengan tetap menggali nilai-nilai kebudayaan asli Indonesia dan dapat memilah nilai-nilai kebudayaan kolonial Belanda dari segi kebaikan dan daya gunanya, sesuai dengan kepribadian bangsa untuk kemajuan bangsa dan kehidupan lebih baik di masa sekarang dan yang akan datang.

Pengertian kebudayaan kolonial dalam tulisan ini menyangkut nilai-nilai kebudayaan kolonial yang telah menjadi praktek keseharian bangsa Indonesia. Nilai-nilai kebudayaan kolonial tersebut merujuk pada definisi nilai yang diungkapkan oleh Louis O. Kattsoff (1987) dan Radbruch (Notohamidjojo, 1975). Kattsoff menyatakan ada dua macam nilai, yaitu nilai intrinsik dan nilai instrumental. Nilai intrinsik adalah nilai dari sesuatu yang sejak semula sudah bernilai, sedangkan nilai instrumental merupakan nilai dari sesuatu karena dapat dipakai sebagai sarana mencapai suatu tujuan. Kemudian pengertian nilai menurut Radbruch (Notohamidjojo, 1975) ada 3 hal penting, yaitu: (1) individualwerte, nilainilai pribadi yang penting untuk mewujudkan kepribadian, (2) gemeninschaftswerte, nilainilai masyarakat, nilai-nilai yang hanya dapat diwujudkan dalam masyarakat manusia, dan (3) werkwerte, nilai-niali dalam karya manusia, umumnya dalam kebudayaan (Darji, 1995). Dengan demikian, kebudayaan Belanda yang bernilai dan harus dipertahankan di lingkungan masyarakat perkebunan sekarang ini, seperti nilai kerja keras dan disiplin dalam bekerja, baik di kantor, pabrik maupun di kebun. Juga di lingkungan rumah atau permukiman di luar jam kerja ketika saling berinteraksi.

Perkebunan besar peninggalan zaman Belanda merupakan bukti kongkrit adanya masyarakat perkebunan di masa lalu, dengan struktur sosial khas yang menggambarkan kebudayaan kolonial. Struktur sosial tersebut dapat diungkap melalui jejak-jejak sejarah perkebunan yang terpenting, di antaranya rumah Administratur (ADM) atau Tuan Tanah (TT), Kepala Tanaman, Kepala Personalia, dan Kepala Afdeling Kebun. Mereka adalah para pejabat tinggi perkebunan.

Para pejabat tinggi perkebunan umumnya membangun rumah tinggal, dengan konsep aristektur tertentu. Pertimbangan kenyamanan, kesehatan, keamanan, keindahan, kemudahan akses dan strategi pengawasan, menjadi faktor utama dalam mendirikan dan mendesain rumah beserta lingkungannya. Konsep tersebut merupakan suatu hasil karya dari kebudayaan manusia yang tidak terlepas dari konsep seni dan teknik. Seperti pendapat Yulianto Sumalyo (2003: 1) bahwa arsitektur dapat dipandang dari dua segi, yaitu seni dan teknik. Seni bangunan termasuk bentuk dan ragam hias, sedangkan teknik bangunan adalah sistem mendirikan bangunan terdiri dari proses perancangan, konstruksi, dekorasi, dan keindahan. Selain bentuk dan gaya arsitektur, bahan dan teknologi yang digunakan dipilih khusus dan dibangun menggunakan teknologi modern ketika itu.

Berdasarkan bentuk, arsitektur, bahan, dan teknologi yang digunakan, rumah pejabat tinggi perkebunan tersebut dapat memberi gambaran tentang struktur sosial. Apa dan bagaimana struktur sosial di lingkungan perkebunan dibalik wujud fisik bangunan, menjadi permasalahan pokok dalam tulisan ini. 
Oleh karena itu, tujuan penelitian adalah menjelaskan struktur sosial dari rumah pejabat tinggi perkebunan, melalui makna simbolik (symbolic meaning) dibalik wujud fisiknya. Struktur sosial perlu diungkap, karena akan diperoleh gambaran kehidupan masyarakat masa lalu pada zaman penjajahan Belanda, beserta kebudayaan penjajah Belanda (nilainilai kebudayaan kolonial).

Tujuan penelitian dapat dicapai dengan pendekatan symbolic meaning Ian Hodder, dengan menerapkan structure concept dan nonverbal communication concept. Makna simbolik benda budaya (objek arkeologi) akan bernilai guna apabila ditinjau dari segi fungsi dan wujud fisik. Benda budaya memiliki arti struktural yang dapat berkomunikasi secara tidak langsung (nonverbal) (Wulan, 2015: 221222). Komunikasi seperti ini merupakan kode budaya (culture code), menunjukkan makna sejarah dalam suatu asosiasi antar benda budaya di masa lalu, karena semua benda dapat dikaji berdasarkan waktu, fungsi, dan penataan objek (Hodder dalam Susan M. Pearce, 2003: 12). ${ }^{\text {iv }}$

Pengertian symbolic meaning adalah arti yang diperoleh melalui simbol-simbol tertentu, tampak pada wujud fisik bangunan dengan fungsi tertentu. Fungsi dan wujud fisik apabila dikaji melalui pendekatan symbolic meaning dengan menerapkan structure concept dan nonverbal communication concept, dapat memberi informasi tentang kehidupan masa lalu.

Struktur sosial adalah tatanan atau susunan sosial yang membentuk kelompokkelompok sosial dalam suatu masyarakat. Struktur sosial memiliki korelasi dengan faktorfaktor ekonomi, golongan-golongan sosial, dan perilaku sosial (Pranoto, 2010: 40). Struktur sosial masyarakat perkebunan mencerminkan struktur masyarakat zaman Hindia Belanda secara umum, yang melahirkan stratifiksi sosial. Stratifikasi sosial masyarakat Hindia Belanda dapat digolongkan menjadi 3 kelas sosial, yaitu: (1) kelas atas terdiri dari orang-orang Eropa, (2) kelas menengah terdiri dari orang-orang Timur Asing (Cina, Arab, India), dan (3) kelas bawah terdiri dari orang-orang pribumi Indonesia asli (Niel, 1984: 15-49) (dalam Nuralia, 2016a: 32).

Konsep struktur atau structure concept dapat menjelaskan sesuatu yang bertransformasi dalam konteks tertentu. Suatu masyarakat akan membangun struktur baru dengan mengubah struktur lama yang telah dibangun sebelumnya, sebagai suatu strategi kelompok (Nuralia, 2016b: 18-19).

Struktur sosial masyarakat perkebunan, baik baru maupun lama, digambarkan melalui wujud fisik bangunan. Struktur bangunan dalam kawasan permukiman perkebunan adalah pola keletakan bangunan (material culture) di dalam lingkungan masyarakat perkebunan (immaterial culture). Setiap aspek dari material culture merupakan pola atau model. Secara umum pola adalah suatu yang bertransformasi secara kontras, sehingga terjadi dikotomi dalam sistem sosial dan distribusi kekuasaan, dengan menekankan pada wholeness (keutuhan pola). Sesuatu yang bertransformasi kontras, struktur dan anti struktur, akan saling menguatkan sebagai cara manusia membangun makna (Hodder, 2013: 24, 30-31, 39).

Struktur masyarakat perkebunan akan mengalami transformasi (perubahan) seiring dengan perubahan dalam bidang politik pemerintahan Belanda. Misalnya kemenangan kaum Liberal di Negeri Belanda berimbas terhadap perubahan politik di Hindia Belanda. Lebih lanjut berdampak pada perubahan kebijakan penguasaan lahan perkebunan dan struktur sosialnya. Lahan perkebunan yang sebelumnya dikuasai oleh pemerintah, berubah menjadi tanah erfpacht, hak sewa dan hak mewariskan dalam waktu lama sampai 75 tahun (Kartodirdjo dan Djoko Surjo, 1991: 80) ${ }^{\mathrm{v}}$ oleh pengusaha swasta asing (Eropa dan Cina). Kemudian dalam struktur sosial lama penduduk Hindia Belanda, etnis Cina berada pada lapisan sosial menengah, sedangkan pada struktur sosial baru di lingkungan perkebunan, orangorang Cina menjadi kelas atas setaraf dengan orang-orang Eropa, sebagai pemilik utama dan pengelola perusahaan perkebunan.

Rumah pejabat tinggi perkebunan merupakan sesuatu yang bertranformasi secara kontras, dikotomi seperti luas dan sempit, bagus dan jelek, dan lain sebagainya, yang berasosiasi dengan bangunan-bangunan perkebunan lainnya, akan menunjukkan keutuhan pola atau struktur keletakan bangunan dalam permukiman emplasemen. Juga bentuk dan model bangunan menunjukkan keutuhan pola gaya arsitektur, campuran antara gaya modern Eropa dan gaya lokal (tradisional Indonesia). Gaya arsitektur tersebut menjadi simbol-simbol yang memberi informasi masa lalu secara nonverbal. 
Konsep komunikasi nonverbal atau nonverbal communication concept pada dasarnya adalah penyampaian pesan dengan tidak bicara langsung antara penyampai pesan dan penerima pesan, serta dianggap satu cara paling tepat dalam mencari informasi masa lalu di masa sekarang ini. Pesan tidak langsung terekam dalam benda budaya milik masyarakat masa lalu, sehingga penerima pesan memahaminya sebagai hasil interpretasi dari pesan tersebut (Wulan, 2015: 224). Komunikasi nonverbal juga merupakan hasil perilaku aktif proxemics dan kinesics, serta material, tampak dalam penataan ruang entitas (Fletcher, 1989: 33). Makna simbolik benda budaya adalah ekspresi pemberi pesan sebagai makna nonverbal.

Proxemics merupakan komunikasi nonverbal antar dua orang atau lebih, yang memiliki jarak dalam ruang tertentu, serta keterikatan hubungan atau relasi tertentu pula. Komunikasi berjarak ini melahirkan empat kategori jarak, yaitu: (1) jarak intim $(0-45 \mathrm{~cm})$, (2) jarak pribadi $(45-120 \mathrm{~cm})$, (3) jarak sosial (120-360 cm), dan (4) jarak publik (360-750 $\mathrm{cm})$. Kategori tersebut berkaitan dengan kedekatan emosional dan atau fungsional antara pelaku relasi, dengan dipengaruhi faktor status, kultur, konteks, evaluasi positif dan negatif, usia, serta jenis kelamin (Littlejohn \& Foss, 2009: 694). Perilaku aktif proxemics dapat dilihat dalam suatu objek atau material, seperti bangunan kolonial perkebunan berupa rumah tinggal pejabat tinggi perkebunan. Dengan demikian, komunikasi nonverbal merupakan komunikasi dalam ruang (spatial) menyangkut jarak antar bangunan dalam lingkungan permukiman emplasemen perkebunan. Kategori jarak antar bangunan dengan melakukan modifikasi bebas secara logis sebagai berikut: (1) Jarak intim (0-45 m), (2) Jarak pribadi (45$120 \mathrm{~m}$ ), (3) Jarak sosial (120-360 m), dan (4) Jarak publik (360-750 m).

\section{METODE}

Berdasarkan permasalahan dan tujuan penelitian yang hendak dicapai, tulisan ini menggunakan metode penelitian arkeologi. Menurut Eleanor Conlin Casella dalam fieldwork di dalam pelaksanaan penelitian arkeologi (2005: 15), proses mencari dan mengumpulkan data dapat dilakukan melalui 4 langkah, yaitu: surface surveys, excavations, archival research, and oral history interviews.
Survei permukaan dilakukan untuk menemukan artefak, keadaan geofisika dan topografi. Ekskavasi dilakukan untuk membuktikan dan menemukan jejak-jejak masa lalu dari artefak yang tekubur dalam tanah. Sementara itu, arsip kolonial sebagai catatan-catatan penting masa lalu terekam atau tersimpan sebagai tulisan bersejarah, serta peta dan foto lama yang dapat digunakan untuk analisis dan interpretasi. Wawancara sejarah lisan dilakukan untuk memperoleh data pribadi atau kolektif, dalam ingatan saksi atau pelaku pada suatu zaman dan komunitas tertentu.

Ada empat tahapan pengolahan data dan analisis dalam mencari makna simbolis dibalik wujud fisik tersebut sebagai berikut.

1. Mengidentifikasi persamaan dan perbedaan fisik bangunan;

2. Merinci dengan tegas perbedaan yang ada;

3. Memberi konteks sosial tertentu pada data yang ada; dan

4. Melakukan interpretasi untuk menjelaskan makna simboliknya.

Dalam tulisan ini pengumpulan data dilakukan dengan studi pustaka terhadap beberapa laporan hasil penelitian yang tidak diterbitkan, pembaruan gambar dan denah, serta buku-buku dan beberapa artikel dalam jurnal dan buku ilmiah.

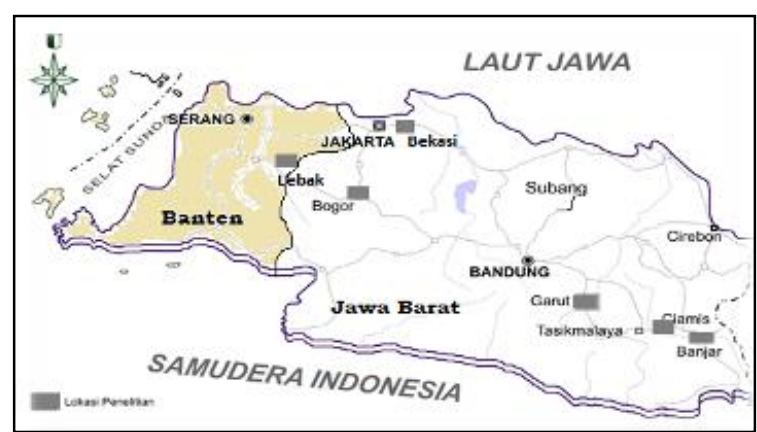

Gambar 1. Kota dan Kabupaten sebagai lokasi penelitian di Jawa Barat dan Banten

(Sumber: Balai Arkeologi Jawa Barat, 2016)

\section{HASIL DAN PEMBAHASAN}

Perkebunan-perkebunan besar warisan zaman Hindia Belanda masih memiliki beberapa tinggalan budaya materi, baik yang ada di lokasi kebun maupun di luar lokasi kebun, dengan bangunan fasilitas perkebunan utama adalah rumah pejabat tinggi perkebunan. Dalam tulisan ini akan dibahas 13 bangunan rumah pejabat tinggi. Ke-13 rumah ini telah 
diteliti pada tahun-tahun yang berbeda, dan telah diseleksi berdasarkan kelengkapan secara fisik bangunan dan informasi kesejarahannya. Rumah pejabat tinggi perkebunan tersebut sebagai berikut.

1. Rumah Administratur Perkebunan Dayeuhmanggung di Garut Kota ${ }^{\text {vi, }}$

2. Rumah Administratur Perkebunan Bunisari Lendra di Garut selatan;

3. Rumah Administratur Perkebunan Gandasoli di Garut Selatan vii;

4. Rumah Tuan Tanah Perkebunan Tambun di Bekasi viii,

5. Rumah Administratur Perkebunan Cisalak Baru di Lebak ${ }^{\mathrm{ix}}$;

6. Rumah Kepala Tanaman Perkebunan Cisalak Baru di Lebak ${ }^{x}$;

7. Rumah Kepala Personalia Perkebunan Cikadu di Lebak ${ }^{\mathrm{xi}}$;

8. Rumah Administratur Perkebunan Bantarjaya di Lebak ${ }^{\text {xii; }}$

9. Rumah Administratur Perkebunan Ciliwung di Cisarua Bogor ${ }^{\text {xiii; }}$

10.Rumah Kepala Afdeling Kebun Perkebunan Cikopo Selatan di Cisarua Bogor ${ }^{\mathrm{xiv}}$;

11.Rumah Administratur Perkebunan Cisaga di Cisaga di Ciamis ${ }^{\mathrm{xv}}$;

12.Rumah Wakil Administratur Perkebunan Batulawang di Cisaga Ciamis ${ }^{\text {xvi }}$;

13.Rumah Administratur Perkebunan Batulawang lama di Pataruman Banjar ${ }^{\text {xvii; }}$ Para pejabat tinggi perkebunan pada umumnya adalah orang-orang Eropa (Belanda), disamping orang-orang keturunan Cina. Mereka tinggal dan menetap di tanah Hindia dengan kehidupan makmur, cenderung berlebihan dari segi sosial ekonomi. Kesuksesan dalam usaha perkebunan besar, membuat mereka tidak ingin kehilangan segala bentuk harta benda dan kesenangan hidup yang telah diraihnya. Para tuan tanah mendirikan rumah tinggal mewah dan megah, dengan akses dan berbagai fasilitas hidup yang memberi kemudahan. Bekas bangunan rumah tinggal tuan tanah dan atau administratur perkebunan, di masa sekarang masih dapat ditemukan dalam bentuk dan arsitektur asli dengan sedikit renovasi. Keaslian terutama tampak pada gaya arsitektur campuran antara Modern Eropa dan tradisional Indonesia atau arsitektur Indis (Sukiman, 2003: 3), atau sering disebut juga arsitektur kolonial.

Arsitektur kolonial dapat digolongkan dalam tiga periode (Handinoto, 1996) dengan karakter khas masing-masing. Pertama, periode 1870-1902, masih menerapkan Indische Empire Style ${ }^{\text {xviii }}$ dengan karakter khas penggunaan kolom-kolom klasik dan denah simetri penuh. Kedua, periode 1902-1920-an, dengan pengaruh besar kemenangan kaum liberal di negeri Belanda dengan ide-ide barunya yang berlanjut ke tanah jajahan, dengan implementasi Politik Etis. Karakter khas periode kedua adalah campuran antara Indische Empire Style dengan Indo-European Style, sehingga disebut sebagai aristektur peralihan atau Arsitektur Transisi (Transition Architecture). ${ }^{\text {xix }}$ Ketiga, periode 1920-an-1940-an, telah memperkenalkan modernisme sebagai gaya Indo-Eropa atau Indo-European Style. Gaya Indo-Eropa memiliki karakter modern Eropa dengan lebih mengedepankan fungsi dalam penggunaan komponen-komponen bangunan, sehingga disebut juga Arsitektur Hindia Baru. Misalnya, penggunan komponen kolom/tiang berfungsi sebagai penyangga atap dan penguat dinding bangunan yang sesungguhnya, bukan sekedar hiasan untuk keindahan dan kemegahan bangunan saja. Dalam perkembangan arsitektur di Hindia Belanda, gaya arsitektur yang menerapkan perpaduan konsep modern Eropa dan tradisional Indonesia, dengan mengambil unsur-unsur yang baik dari keduanya, dikenal sebagai masa "ekletisisme" (campuran).

Istilah arsitektur Indis menurut Djoko Soekiman dan beberapa istilah yang digunakan Handinoto (Indische Empire Style, IndoEuropean Style, Transition Architecture), samasama sebagai bentuk arsitektur campuran dari beberapa unsur arsitektur Eropa dan tradisional Indonesia. Indo-European Style adalah gaya modern Eropa (baru) diaplikasikan pada pendirian bangunan secara utuh, dengan menghilangkan gaya lama yang dominan dalam Indische Empire Style. Transition Architecture adalah peralihan dari Indische Empire Style menuju Indo-European Style. Bangunan Transition Architecture berusaha menerapkan konsep modern Eropa, tetapi belum sepenuhnya meninggalkan beberapa unsur dalam konsep Indische Empire Style. Gaya Transition Architecture dapat dikatakan sebagai gaya perpaduan antara konsep Indische Empire Style dan Indo-Euroean Style, yang memuat sebagian karakter arsitektur dari keduanya. 


\section{Konsep Struktur Pada Rumah Pejabat Tinggi Perkebunan}

Rumah pejabat tinggi perkebunan memiliki struktur atau pola umum, baik secara eksternal atau tata letak dalam ruang permukiman maupun secata internal atau pembagian ruang bangunan. Secara eksternal dilihat dari keletakan bangunan dari jalan raya serta keletakan bangunan dari emplasemen permukiman perkebunan dan lokasi kebun. Secara internal dilihat dari pembagian dan jumlah ruang. Secara umum ada tiga pola keletakan dan dua pola pembagian ruang. Tiga pola keletakan bangunan, yaitu:

1. Dekat dari jalan raya, berada dalam kawasan emplasemen perkebunan yang terletak di tepi jalan raya. Biasanya berada dalam komplek kantor induk administrasi atau komplek pabrik (antara $\pm 10-100$ meter dari jalan raya);

2. Jauh dari jalan raya, berada dalam kawasan afdeling kebun dengan komplek permukiman tersendiri (lebih dari \pm 100 meter, kadang-kadang berbeda desa atau kecamatan;

3. Tepi jalan raya, berada tepat di pinggir jalan raya, terpisah dari kebun dan pabrik, tidak dalam kawasan emplasemen perkebunan.
Secara administratif bisa berbeda desa dan kecamatan, jauhnya jarak dari rumah ke lokasi kebun lebih dari \pm 1 kilometer.

(lihat tabel 1, gambar 2 dan 3).

Pola pertama ditunjukan oleh rumah ADM Bunisari Lendra, ADM Cisalak Baru, Kepala Tanaman Cisalak Baru, ADM Cisaga, dan Kepala Tanaman Batulawang. Kelima rumah ini berada dalam kawasan emplasemen permukiman perkebunan, berdekatan dengan bangunan-bangunan perkebunan lainnya. Pola kedua seperti rumah ADM Gandasoli, Kepala Personalia Cikadu, ADM Bantarjaya, ADM Ciliwung, Kepala Afdeling Cikopo Selatan, dan ADM Batulawang. Keenam rumah terletak di dalam lokasi kebun atau tidak berada di kawasan emplasemen, berjauhan dengan bangunan-bangunan perkebunan lainnya. Pola ketiga seperti rumah ADM Dayeuhmanggung dan rumah TT Tambun, terletak di luar lokasi perkebunan, sehingga tidak berasosiasi dengan bangunan perkebunan lainnya.

Pola pertama menunjukkan bahwa struktur kekuasaan terbentuk dalam dua lapisan, yaitu atas (pemilik) dan bawah (buruh). Pemilik sebagai pengelola bisa langsung terjun ke lapangan setiap waktu, memberi intruksi dan mengawasi langsung, walau ada asisten atau

Tabel 1. Pola keletakan Rumah Pejabat Tinggi Perkebunan

\begin{tabular}{|c|c|c|c|c|c|}
\hline No & $\begin{array}{l}\text { Rumah Pejabat Tinggi } \\
\text { Perkebunan }\end{array}$ & $\begin{array}{l}\text { Keletakan Bangunan dari } \\
\text { Jalan Raya }\end{array}$ & $\begin{array}{l}\text { Keletakan Bangunan dari Lokasi } \\
\text { Perkebunan }\end{array}$ & $\begin{array}{l}\text { Bagian } \\
\text { Bangunan }\end{array}$ & $\begin{array}{l}\text { Jumlah } \\
\text { Ruang }\end{array}$ \\
\hline 1. & $\begin{array}{l}\text { ADM } \\
\text { Dayeuhmanggung }\end{array}$ & $\begin{array}{l}\text { di tepi jalan raya, } \\
\text { Garut Kota - Garut }\end{array}$ & $\begin{array}{l}\text { Terpisah \& berjauhan dari kebun } \\
\text { dan emplasemen }\end{array}$ & $\begin{array}{l}\text { Dua: inti, } \\
\text { tambahan }\end{array}$ & 24 ruang \\
\hline 2. & ADM Bunisari Lendra & $\begin{array}{l}\text { Dekat jalan raya, } \\
\text { Cisompet - Garut }\end{array}$ & $\begin{array}{l}\text { Dalam satu kawasan } \\
\text { emplasemen, berdekatan }\end{array}$ & $\begin{array}{l}\text { Dua: inti, } \\
\text { tambahan }\end{array}$ & 22 ruang \\
\hline 3. & ADM Gandasoli & $\begin{array}{l}\text { Jauh dari jalan raya, } \\
\text { Cisompet - Garut }\end{array}$ & $\begin{array}{l}\text { Dalam satu kawasan kebun, } \\
\text { berjauhan }\end{array}$ & $\begin{array}{l}\text { Dua: inti, } \\
\text { tambahan }\end{array}$ & 14 ruang \\
\hline 4. & TT Tambun & $\begin{array}{l}\text { Di tepi jalan raya, } \\
\text { Tambun - Bekasi }\end{array}$ & $\begin{array}{l}\text { Terpisah \& berjauhan dari kebun } \\
\text { dan emplasemen, }\end{array}$ & $\begin{array}{l}\text { Satu : inti } \\
\text { (2 lantai) }\end{array}$ & 23 ruang \\
\hline 5. & ADM Cisalak Baru & $\begin{array}{l}\text { Dekat jalan raya, } \\
\text { Rangkasbitung - Lebak }\end{array}$ & $\begin{array}{l}\text { Dalam satu kawasan emplasemen, } \\
\text { berdekatan }\end{array}$ & $\begin{array}{l}\text { Dua: inti, } \\
\text { mess }\end{array}$ & 18 ruang \\
\hline 6. & $\begin{array}{l}\text { Ka. Tanaman Cisalak } \\
\text { Baru }\end{array}$ & $\begin{array}{l}\text { Dekat jalan raya, } \\
\text { Rangkasbitung - Lebak }\end{array}$ & $\begin{array}{l}\text { Dalam satu kawasan emplasemen, } \\
\text { berdekatan }\end{array}$ & Satu (inti) & 16 ruang \\
\hline 7. & Ka.Personalia Cikadu & $\begin{array}{l}\text { Jauh dari jalan raya, } \\
\text { Maja - Lebak }\end{array}$ & $\begin{array}{l}\text { Di dalam kawasan kebun afdeling, } \\
\text { berjauhan }\end{array}$ & Satu (inti) & 14 ruang \\
\hline 8. & ADM Bantarjaya & $\begin{array}{l}\text { Jauh dari jalan raya, } \\
\text { Cimarga - Lebak }\end{array}$ & $\begin{array}{l}\text { Dalam satu kawasan kebun, } \\
\text { berjauhan }\end{array}$ & Satu : inti & 12 ruang \\
\hline 9. & ADM Ciliwung & $\begin{array}{l}\text { Jauh dari jalan raya, } \\
\text { Cisarua - Bogor }\end{array}$ & $\begin{array}{l}\text { Dalam satu kawasan kebun, } \\
\text { berjauhan }\end{array}$ & $\begin{array}{l}\text { Dua: inti, } \\
\text { tambahan }\end{array}$ & 22 ruang \\
\hline 10. & $\begin{array}{l}\text { Ka. Afd. Kebun Cikopo } \\
\text { Selatan }\end{array}$ & $\begin{array}{l}\text { Jauh dari jalan raya, } \\
\text { Cisarua - Bogor }\end{array}$ & $\begin{array}{l}\text { Dalam satu kawasan kebun, } \\
\text { berdekatan }\end{array}$ & Satu: inti & 11 ruang \\
\hline 11. & ADM Cisaga & $\begin{array}{l}\text { Dekat jalan raya, } \\
\text { Cisaga - Ciamis }\end{array}$ & $\begin{array}{l}\text { Dalam satu kawasan emplasemen, } \\
\text { berdekatan }\end{array}$ & $\begin{array}{l}\text { Dua: inti, } \\
\text { tambahan }\end{array}$ & 18 ruang \\
\hline 12. & $\begin{array}{l}\text { Ka.Tanaman } \\
\text { Batulawang Ciamis }\end{array}$ & $\begin{array}{l}\text { Dekat jalan raya, } \\
\text { Cisaga - Ciamis }\end{array}$ & $\begin{array}{l}\text { Dalam satu kawasan emplasemen, } \\
\text { berdekatan }\end{array}$ & $\begin{array}{l}\text { Dua: inti, } \\
\text { tambahan }\end{array}$ & 16 ruang \\
\hline 13. & $\begin{array}{l}\text { ADM Batulawang } \\
\text { lama di Banjar }\end{array}$ & $\begin{array}{l}\text { Jauh dari jalan raya, } \\
\text { Pataruman - Banjar }\end{array}$ & $\begin{array}{l}\text { Dalam satu kawasan emplasemen, } \\
\text { berdekatan }\end{array}$ & $\begin{array}{l}\text { Dua: inti, } \\
\text { tambahan, }\end{array}$ & 27 ruang \\
\hline
\end{tabular}

Sumber: Laporan Penelitian Arkeologi tahun 2007, 2008, 2009, 2012, 2013, 2014 
pengawas yang siap membantunya. Dalam hal ini kebudayaan kolonial (nilai-nilai) terwujud dalam hierarki kekuasaan yang tidak terlalu kaku, sehingga melahirkan perilaku sosial positif. Lebih lanjut dapat dijelaskan bahwa dalam struktur organisasi perusahaan perkebunan besar zaman Belanda, hierarki kekuasaan mengandung kebudayaan kolonial (nilai-nilai) penjajah Belanda. Hal ini terjadi karena penguasa tertinggi atau pejabat tinggi perkebunan adalah orang-orang Belanda atau orang-orang Eropa (penjajah). Pada umumnya pejabat tinggi perkebunan sebagai penjajah, akan berperilaku tidak sama terhadap dua golongan yang berbeda. Ketika ia berhadapan dengan orang-orang dari golongan yang sama dengannya (Eropa) akan bersikap sopan dan penuh perhatian. Akan tetapi, pada saat berinteraksi dengan orang-orang pribumi (Indonesia) sebagai golongan yang dijajah, ia akan mengambil jarak, cenderung tegas dan penuh tekanan atau perintah, karena mereka berbeda dalam pekerjaan dan status sosial. Dalam pola pertama tersebut, pejabat tinggi perkebunan (penjajah) langsung berinteraksi dengan buruh kebun (yang dijajah), sehingga komunikasi terjalin lebih akrab dan nyaman. Perbedaan kedudukan dan warna kulit tidak begitu terasa, karena komunikasi yang terjalin langsung tanpa perantara. Kondisi inilah yang disebut sebagai perilaku sosial positif dari pejabat tinggi perkebunan kepada buruh kebun (pegawai rendahan dari kelas bawah).

Selain hubungan yang tidak kaku dan perilaku positif pejabat tinggi, dalam pola pertama tersebut, juga menunjukkan tidak adanya jarak tegas memisahkan masyarakat perkebunan dengan dunia luar atau non perkebunan. Keletakan rumah dekat jalan raya juga menunjukkan indikasi kedekatan hubungan dan keterbukaan dengan lingkungan sekitar, baik dengan karyawan (buruh) kebun maupun dengan masyarakat nonperkebunan. Interaksi antara pejabat tinggi dan karyawan serta masyarakat sekitarnya sering dilakukan, sehingga dimungkinkan telah terjadi pencampuran dua budaya (Barat dan Timur) terekspresikan dalam aktivitas kerja dan nonkerja. Sangat mungkin buruh perkebunan juga berasal dari perkampungan dekat lokasi kebun, ${ }^{\mathrm{xx}}$ sehingga memudahkan akses keluar masuk dan hubungan saling menguntungkan. Perkebunan mendapat buruh murah dan mudah, sedangkan penduduk kampung berkesempatan mendapat tambahan penghasilan dari upah buruh kebun paruh waktu, disamping sebagai petani penggarap atau pemilik tanah. Bagi buruh tani (tanpa lahan garapan / tanah sendiri), bisa bekerja menjadi buruh kebun penuh waktu yang mendapat upah rutin secara langsung.

Pola kedua juga menujukkan struktur kekuasaan yang terdiri dari dua lapisan, yaitu
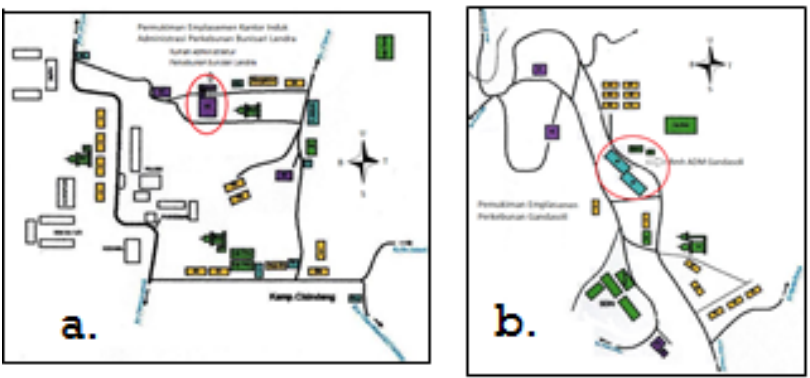

Keterangan gambar: letak rumah dalam lingkaran merah

a. ADM Bunisari Lendra

b. ADM Gandasoli

c. ADM Dayeuhmanggung

d. Ka.Tanaman (1) dan ADM
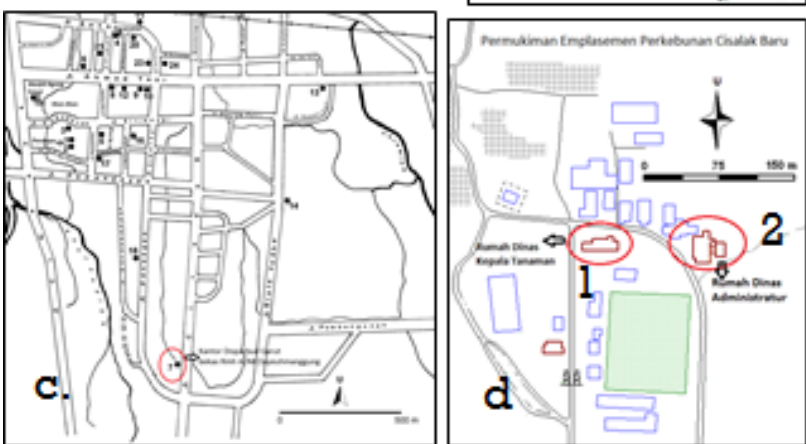

Cisalak Baru (2)

Gambar 2. Tata letak Rumah Pejabat Tinggi Perkebunan dalam wilayah emplasemen perkebunan dan kota (Dayeuhmanggung)

(Sumber: Laporan Penelitian Arkeologi Tahun 2007, 2008, 2012) 
atas dan bawah. Intruksi dan pengawasan bisa langsung dilakukan sendiri setiap hari, walaupun ada asisten. Pejabat tinggi perkebunan hanya berhubungan intens dengan buruh kebun. Interaksi dengan penduduk kampung sangat kurang, bahkan mungkin tidak pernah dilakukan. Sebagian besar buruh kebun tinggal di perumahan buruh yang disediakan perusahaan. Hubungan dengan dunia luar menjadi tertutup, komunitas baru buruh di lokasi kebun menjadi terisolasi dan teralienasi, sehingga menimbulkan krisis baik pada tingkat pribadi maupun kolektif. ${ }^{x i}$ Sisi positif dari keletakan rumah pejabat tinggi yang jauh keramaian adalah dapat bekerja fokus, melakukan instruksi dan pengawasan langsung, sehingga para buruh bekerja lebih disiplin dan diperkirakan hasil yang diperoleh sesuai target yang diinginkan perusahaan.

Pola ketiga, rumah pejabat berada di luar lokasi perkebunan, tidak ada asosiasi dengan bangunan-bangunan perkebunan lainnya dan tidak ada interaksi intens atau hanya sesekali ketika melakukan kontrol ke lokasi kebun. Dalam hal ini instruksi kerja keseharian telah diwakilkan kepada pengawas atau asisten yang bekerja di lapangan. Pengawas/asisten sebagai perantara berperan sangat penting. Struktur kekuasan terbentuk menjadi 3 lapisan, yaitu pejabat, pengawas/asisten (perantara), dan buruh/karyawan. Hubungan antara pejabat dan buruh sebatas hubungan kerja tidak langsung, sedangkan hubungan nonkerja hampir tidak terjadi. Akan tetapi, pejabat tinggi perkebunan tersebut dimungkinkan memiliki interaksi sosial nonkerja dengan penduduk nonperkebunan. Administratur dan pejabat tinggi lainnya menempati jabatan di luar struktur kekuasan Pemerintah Hindia Belanda. ${ }^{x x i i}$

Rumah penjabat tinggi perkebunan berdasarkan tata ruang dalam rumah tinggal, memiliki pola umum (tabel 1, gambar 4 dan 5), terdiri dari 2 pola ruang bangunan, yaitu: (1) dua bagian bangunan (inti dan tambahan), dan (2) satu bagian bangunan (inti). Pola pertama tampak pada rumah ADM Dayeuhmanggung, ADM Bunisari Lendra, ADM Gandasoli, ADM Cisalak Baru, ADM Ciliwung, ADM Cisaga, Kepala Tanaman Batulawang Ciamis, dan ADM Batu Lawang Banjar. Kemudian pola kedua ditunjukkan oleh rumah Tuan Tanah Tambun, Kepala Tanaman Cisalak Baru, Kepala Personalia Cikadu, Kepala Afdeling Kebun Cikopo Selatan, dan ADM Bantarjaya.
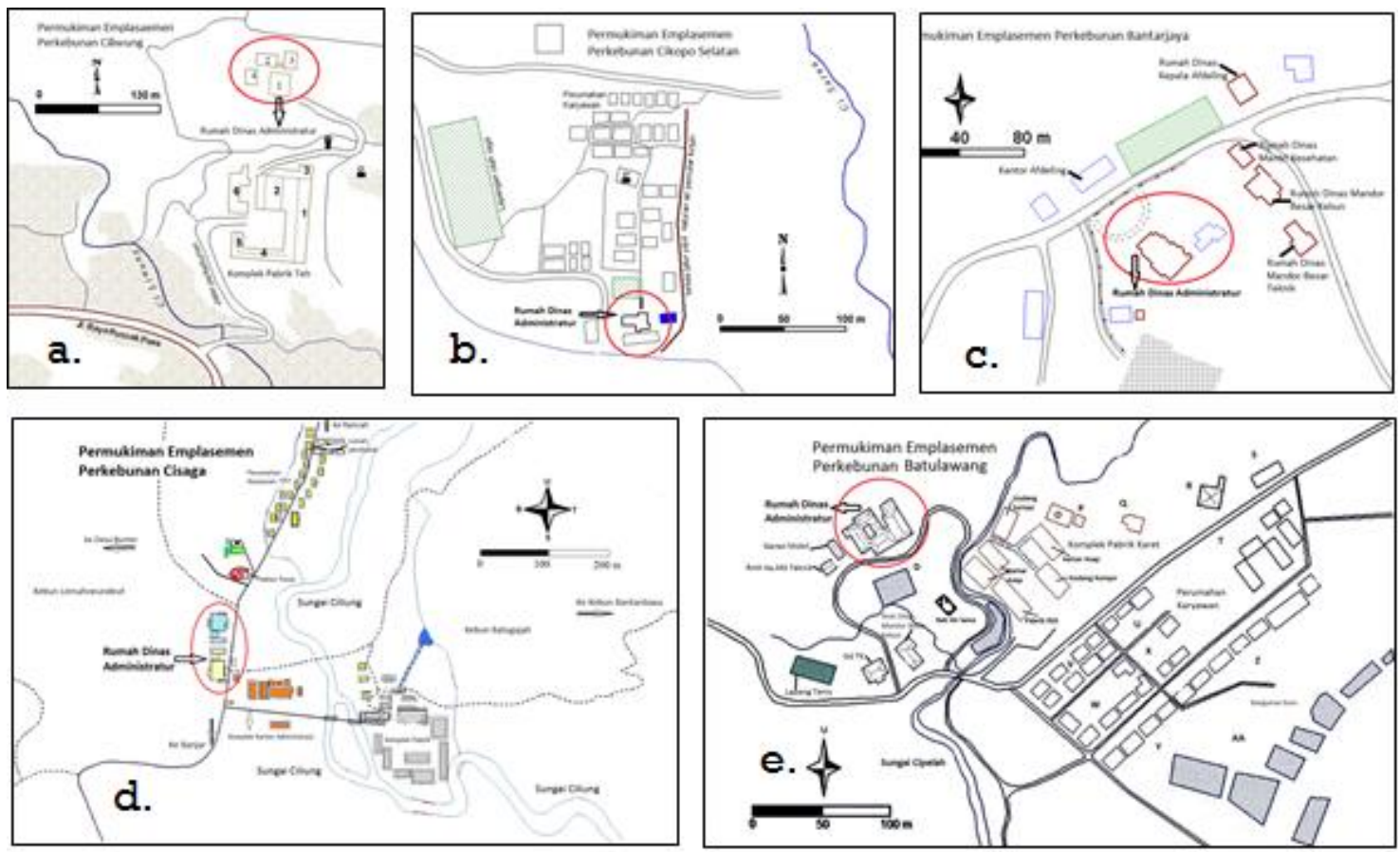

Keterangan gambar dalam lingkaran merah: a. ADM Ciliwung, b. Ka.Afd.Cikopo Selatan, c. ADM Bantarjaya, d. ADM Cisaga, dan e. ADM Batulawang.

Gambar 3. Tata Letak Rumah Pejabat Tinggi Perkebunan dalam permukiman emplasemen perkebunan (Sumber: Laporan Penelitian Arkeologi Tahun 2012, 2013, dan 2014) 

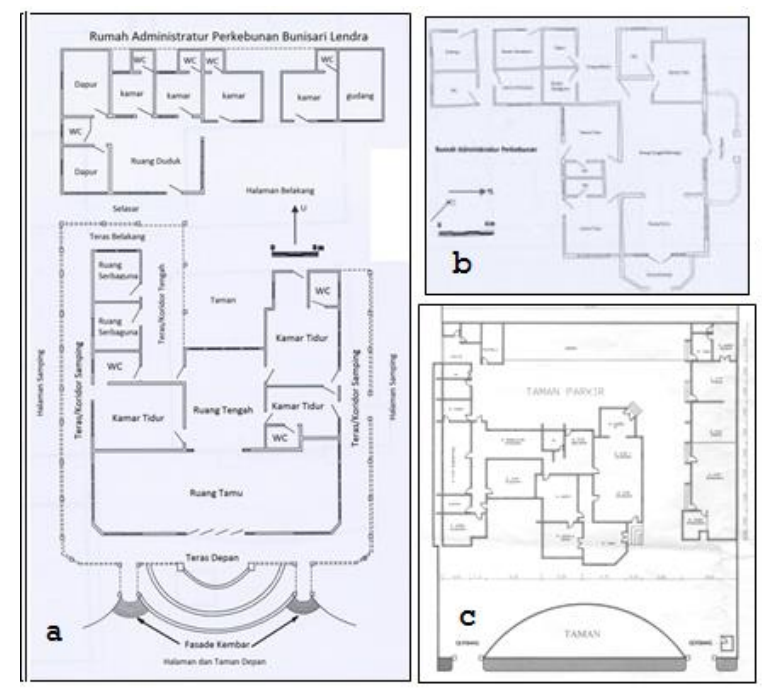

Keterangan Denah:

a. Rumah ADM Bunisari Lendra

b. Rumah ADM Gandasoli

c. Rumah ADM Dayeuhmanggung

d. Rumah Kepala Personalia Cikadu

e. Rumah ADM Bantarjaya
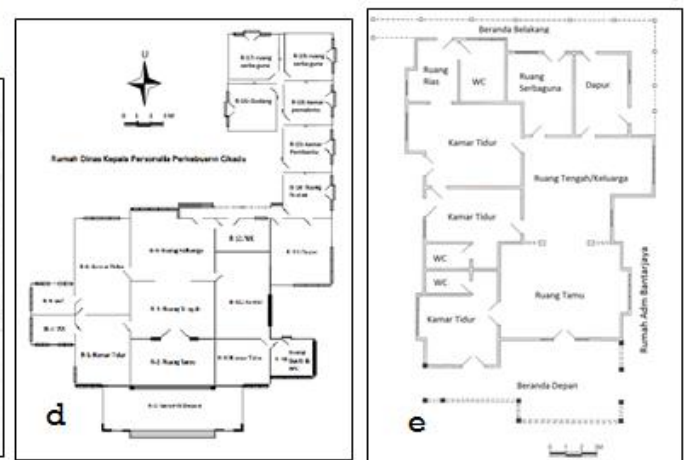

Gambar 4. Denah Rumah Pejabat Tinggi Perkebunan

(Sumber: Dok. Balai Arkeologi Bandung 2007, 2008, 2012)

Pola pertama dengan dua bagian bangunan (inti dan tambahan) secara umum adalah rumah Administratur. Kedua bagian bangunan dihubungkan oleh selasar atau koridor beratap dan bertiang, sebagai ruang antara atau transisi. Bangunan inti ditempati oleh administratur dan keluarga, sedangkan bangunan tambahan sebagai ruang pelayanan dan gudang, ditempati oleh para pembantu rumah tangga. Bangunan inti menunjukkan status sosial tinggi, karena orang yang tinggal di dalamnya adalah pejabat tinggi perkebunan. Bangunan tambahan menunjukkan status sosial rendah/bawah, yang ditempati para pembantu rumah tangga atau pelayan/buruh. Sementara itu, selasar atau koridor digunakan oleh administratur dan keluarga ketika akan memberi perintah dan membutuhkan pelayanan dari pembantu. Demikinan juga, para pembantu akan melewati selasar menuju bangunan inti untuk memberikan pelayanan. Dari aktivitas fisik menyimbolkan bahwa interaksi yang terjadi antara kelas atas dan kelas bawah tidak secara langsung, ada kelas menengah yang menjadi perantara atau menjembatani interaksi di antara keduanya. Hal ini menunjukkan bahwa lapisan sosial tersebut mencerminkan struktur sosial dalam masyarakat perkebunan terdiri dari tiga golongan/kelas, yaitu: (1) kelas atas, (2) kelas menengah, dan (3) kelas bawah.

Pola kedua dengan satu bagian bangunan (inti) secara umum adalah rumah pejabat tinggi perkebunan jajaran kedua (wakil administratur dan kepala afdeling), walaupun ada juga rumah
ADM dan TT. Bangunan inti ditempati kepala afdeling dan keluarga, sedangkan para pembantu atau pelayan menempati bangunan lain yang tidak menyatu dengan bangunan inti. Tidak ada selasar yang menghubungkan tempat tinggal kepala afdeling dan tempat tinggal pembantu rumah tangga. Contoh kasus adalah rumah Kepala Afdeling Kebun Cikopo Selatan. Hal ini menunjukkan hanya ada dua lapisan sosial, yaitu lapisan atas dan lapisan bawah. Kepala afdeling kebun bisa langsung memberi instruksi kepada karyawan atau buruh kebun. Hubungan di antara mereka lebih akrab, tidak kaku atau tidak terlalu formal. Keadaan ini berbeda dengan kasus Tuan Tanah Tambun yang menempati rumah dengan satu bangunan inti saja. Interaksi yang terjadi antara tuan tanah dan para pekerjanya sangat formal dan kaku. Tuan Tanah dan keluarga memiliki jarak yang jelas dengan para pembantu, tidak ada keterikatan emosional antara Tuan Tanah dan para pelayan atau antara si majikan dan buruh. Tuan Tanah bekerja sebagai pemilik dan pengelola perusahan, baik langsung dikerjakan sendiri atau dibantu asisiten dengan kontrol atau pengawasan tetap berada di tangannya. Para pembantu rumah tangga melaksakan tugasnya dengan tidak ikut campur dalam urusan pribadi majikan. Kehidupan keseharian berjalan tenang dan masing-masing sibuk dengan urusannya sendiri-sendiri.

Selain ada pembagian bangunan, rumah pejabat tinggi perkebunan memiliki jumlah ruang berbeda-beda. Setiap bangunan memiliki 
jumlah tertentu, disesuaikan dengan kebutuhan penghuninya. Makna yang terkandung dibalik beragamnya jumlah ruangan menunjukkan bahwa semakin banyak ruang, semakin banyak aktivitas di dalam rumah yang dilakukan. Juga diperkirakan berhubungan dengan jumlah anggota keluarga. Semakin banyak anggota keluarga, semakin banyak jumlah ruang yang dibutuhkan. Banyaknya ruang memerlukan bengunan lebih luas di atas lahan yang juga lebih luas. Hal ini bisa juga menunjukkan kesusksesan perusahaan dan kebesaran kekuasaan yang dimiliki administratur atau tuan tanah, bahwa semakin besar dan banyaknya ruang dalam rumah pejabat tinggi perkebunan, semakin besar perusahaan yang dijalankannya.

Pada zaman Hindia Belanda, posisi administratur ditempati oleh orang-orang Belanda atau pengusaha swasta asing (Eropa) lainnya, berkulit putih, totok atau peranakan (Indo-Eropa), atau orang-orang Timur Asing yang dipersamakan kedudukannya. Sementara itu, para pembantu rumah tangga dan atau buruh perkebunan, umumnya berasal dari etnis Timur yang memiliki kulit berwarna. Pejabat tinggi perkebunan sebagai kelas sosial atas identik dengan ras Eropa (Barat) dan buruh perkebunan sebagai kelas sosial bawah identik dengan ras Asia (Timur). Instruksi ras Barat harus dilaksanakan ras Timur. Nilai-nilai kolonial tersebut berlaku dalam hubungan kerja dan hubungan nonkerja. Pada kenyataan yang terjadi, baik hubungan kerja maupun nonkerja tidak terpisah secara tegas. Sementara itu, golongan perantara terdiri dari dua jenis, orangorang Eropa dan orang-orang pribumi asli.

Perbedaan rasa dan kedudukan dalam situasi kolonial tersebut menimbulkan interaksi khusus, berupa buruh dan majikan. Dalam hal ini terjadi perpanjangan birokrasi, intruksi dari administratur melalui beberapa tangan, dimulai pengawas Eropa (opzichter) atau mandor kolonial, mandor pribumi atau ketua regu buruh (ploegbass), terakhir kepada buruh. Kemudian pejabat tinggi perkebunan sebagai tuan tanah keturunan Cina merupakan kasus khusus. Dalam stuktur masyarakat Hindia Belanda secara umum, keturunan Cina menempati lapisan sosial kedua atau kelas menengah. Semantara itu, dalam struktur masyarakat perkebunan Tuan Tanah Cina berada pada lapisan sosial pertama atau kelas atas.
Pada zaman Hindia Belanda, struktur organisasi perusahaan perkebunan besar milik swasta asing (Nuralia, 2016b: 34-35) secara umum, yang mencerminkan struktur yang hierarkis dari kelas atas sampai kelas bawah bawah sebagai berikut.

1. Administratur (administrateur);

2. Wakil Administratur (employe atau kepala tanaman atau kepala personalia);

3. Pengawas (opzichter) dan Asisten atau mandor kolonial;

4. Ketua Regu (ploegbass) atau mandor pribumi; dan

5. Buruh (kulie) kebun dan pabrik.

Seiring dengan kemajuan perusahaan kebutuhan akan tenaga ahli dan para pekerja perkebunan menjadi bertambah. Muncul jabatan baru dalam organisasi perusahaan, yaitu sinder afdeeling ${ }^{\text {xxii }}$ atau kepala bagian. Posisinya berada di antara administratur dan pengawas, berada dibawah wakil administratur, tetapi bertanggung jawab langsung kepada administartur. Demikian juga dengan mandor pribumi dan buruh kebun, mengalami penambahan karena kebutuhan akan tenaga kerja kasar semakin besar, mengingat luas kebun dan hasil yang diperoleh bertambah banyak. Struktur perkebunan (Nuralia, 2016b: 37-39) tersebut digambarkan sebagai berikut.

1. Administratur (administrateur);

2. Wakil Administratur (employe atau kepala tanaman atau kepala personalia);

3. Kepala Bagian (sinder afdeeling);

4. Pengawas (opzichter) dan Asisten atau mandor kolonial;

5. Ketua Regu (ploegbass) atau mandor pribumi:

a. Mandor (mandor besar)

b. Wakil mandor

6. Buruh (kulie) kebun dan pabrik:

a. Buruh tetap

b. Buruh lepas

Struktur perkebuan tersebut menjadi dasar hubungan kerja dan nonkerja dalam lingkungan perkebunan. Status sosial yang berbeda berdasarkan pembagian kerja dan penghasilan atau gaji yang diperoleh. Hal tersebut berpengaruh kepada tata karma di antara mereka. Segala ucapan dan tindakan atau perilaku sosial menunjukkan status sosial secara individu. Seorang buruh atau mandor pribumi tidak akan secara langsung punya keberanian untuk menyapa atau menyampaikan keluhan 

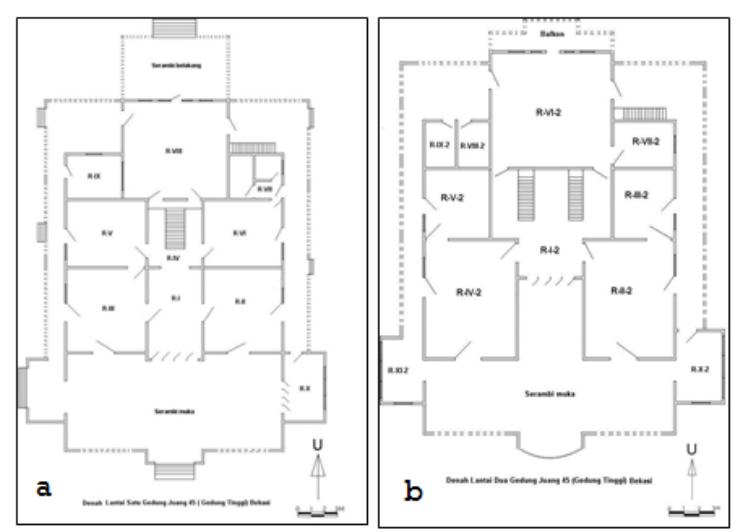

Keterangan Denah:

a. Rumah Tuan Tanah Tambun lt-1

b. Rumah Tuan Tanah Tambun lt-2

c. Rumah ADM Cisaga

d. Rumah Kepala Tanaman

Batulawang

e. Rumah ADM Cisalak Baru

f. Rumah ADM Batulawang
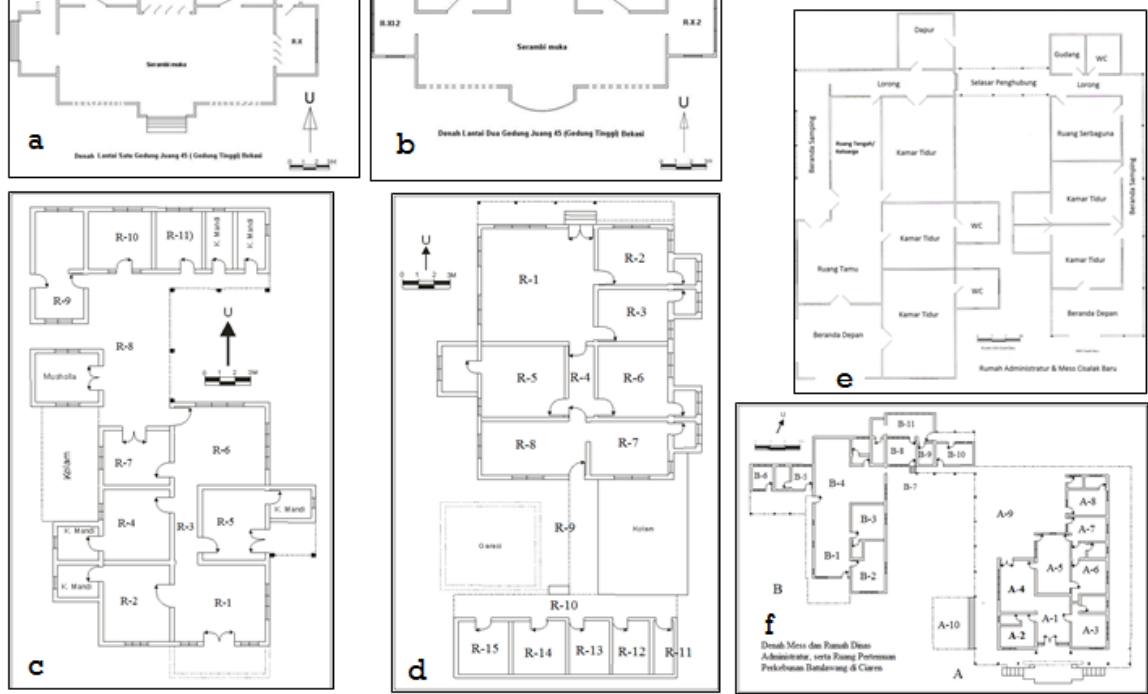

Gambar 5. Denah Rumah Pejabat Tinggi Perkebunan

(Sumber: Dok. Balai Arkeologi Bandung, 2009, 2012, dan 2014)

kepada pejabat di atasnya. Ada aturan tidak tertulis yang mengharuskan mereka menahan diri untuk tidak mengekspresikan segala pikiran dan perasaannya. Ada prosedur yang harus dilewati secara hierarkis, dan belum tentu akan mendapat respon seperti yang diharapkan.

\section{Konsep Komunikasi Nonverbal Pada Rumah Pejabat Tinggi Perkebunan}

Komunikasi nonverbal menggunakan bahasa tidak langsung. Salah satunya melalui simbol-simbol dalam bentuk fisik bangunan. Komunkasi nonverbal sebaga media, alat berkomunikasi antara penyampai pesan di masa lalu dan penerima pesan di masa sekarang. Keduanya berkomunikasi tentang kebudayaan penjajah dan yang dijajah. Bahasa merupakan alat penghubung, verbal atau nonverbal. Kluckhohn menulis Human culture without language is unthinkable, budaya manusia tanpa bahasa tidak bisa dipikirkan. Apa jadinya kehidupan manusia tanpa bahasa, karena bahasa sangat berperan dalam proses internalisasi budaya, termasuk bahasa nonverbal yang terkait dengan unsur-unsur spatial, teritorial, marka, dan artefak (Wulan, 2015: 222).

Keberadaan rumah pejabat tinggi perkebunan dengan arsitektur kolonial yang masih asli, membuktikan kehadiran orang asing (penjajah) yang membentuk koloni baru di lokasi perkebunan, sebagai usahanya dalam memenuhi kebutuhan ekonomi, sosial dan politiknya. Kaum penjajah tersebut membawa budaya dari tanah asalnya ke daerah yang memiliki budaya lokal setempat, yang tidak mudah mereka terima. Bahkan mereka beranggapan bahwa budaya lokal (asli) adalah inferior dibandingkan dengan budaya mereka yang superior. Hal ini menyebabkan terjadinya pertentangan antara dua budaya atau oposisi biner antara budaya Barat dan budaya Timur. Masyarakat asli (pribumi Indonesia) dengan budaya timurnya, sejak masa kolonial dan sesudahnya, tetap melakukan perlawananperlawanan terhadap kondisi dominasi kolonialisme dan imperialisme. Keadaan ini juga menujukkan adanya akulturasi dan asimilasi budaya, baik secara material maupun immaterial, maka interaksi antara lingkungan 
tempat tinggal dan identitas individu yang tinggal di dalamnya akan selalu terjadi.

Akulturasi secara material terwujud dalam gaya arsitektur campuran bangunan rumah pejabat tinggi perkebunan. Arsitektur campuran atau arsitektur Indis merupakan perpaduan unsur-unsur gaya arsitektur Eropa dan gaya lokal (tradisional Indonesia). Arsitektur Indis disebut juga gaya modern Eropa (Hindia Baru) yang telah menyesuaikan dengan iklim setempat. Unsur-unsur arsitektur Eropa terlihat dari volume bangunan besar dan luas, atap dan langit-langit tinggi, bentuk bukaan besar dan tinggi, lantai ditinggikan dari permukaan tanah dengan anak tangga, memiliki tiang bergaya tuscan (Gill, 2002: 113). Unsurunsur arsitektur lokal tampak dari bentuk atap limasan gaya Jawa atau parahu kumereb gaya Sunda dengan penutup atap berbahan genteng tanah liat. Gaya Hindia Baru tersebut lahir sebagai bentuk Adaptasi dengan lingkungan setempat yang beriklim tropis basah dengan banyaknya bukaan (pintu, jendela, ventilasi), adanya beranda (teras) depan dan beranda belakang, bahkan teras samping, yang terbuka dan menghadap taman dengan pohon-pohon rindang (Sukada, 2002: 120). Keberadaan taman dengan pohon-pohon besar di sekeliling rumah, menandakan mulai berkembangnya kota taman tropis dan vila kolonial Hindia Belanda awal abad ke-20 (Passchier, 2002: 124).

Gaya arsitektur campuran dikenal juga sebagai gaya Indo-Eropa atau Indo-European Style, yang menjadi trend di awal abad ke-20, dengan karakter khas lebih mengedepankan fungsi dan menghilangkan kolom-kolom besar dan megah berornamen rumit. Tampilan fisik yang cukup menonjol (tabel 2) dari 13 rumah, dapat dikelompokkan, sebagai berikut.

1. Façade kembar dan tangga: rumah ADM Bunisari Lendra, ADM Ciliwung, ADM Batulawang, dan Kepala Afdeling Cikopo Selatan

2. Tahun pendirian: paling tua adalah rumah
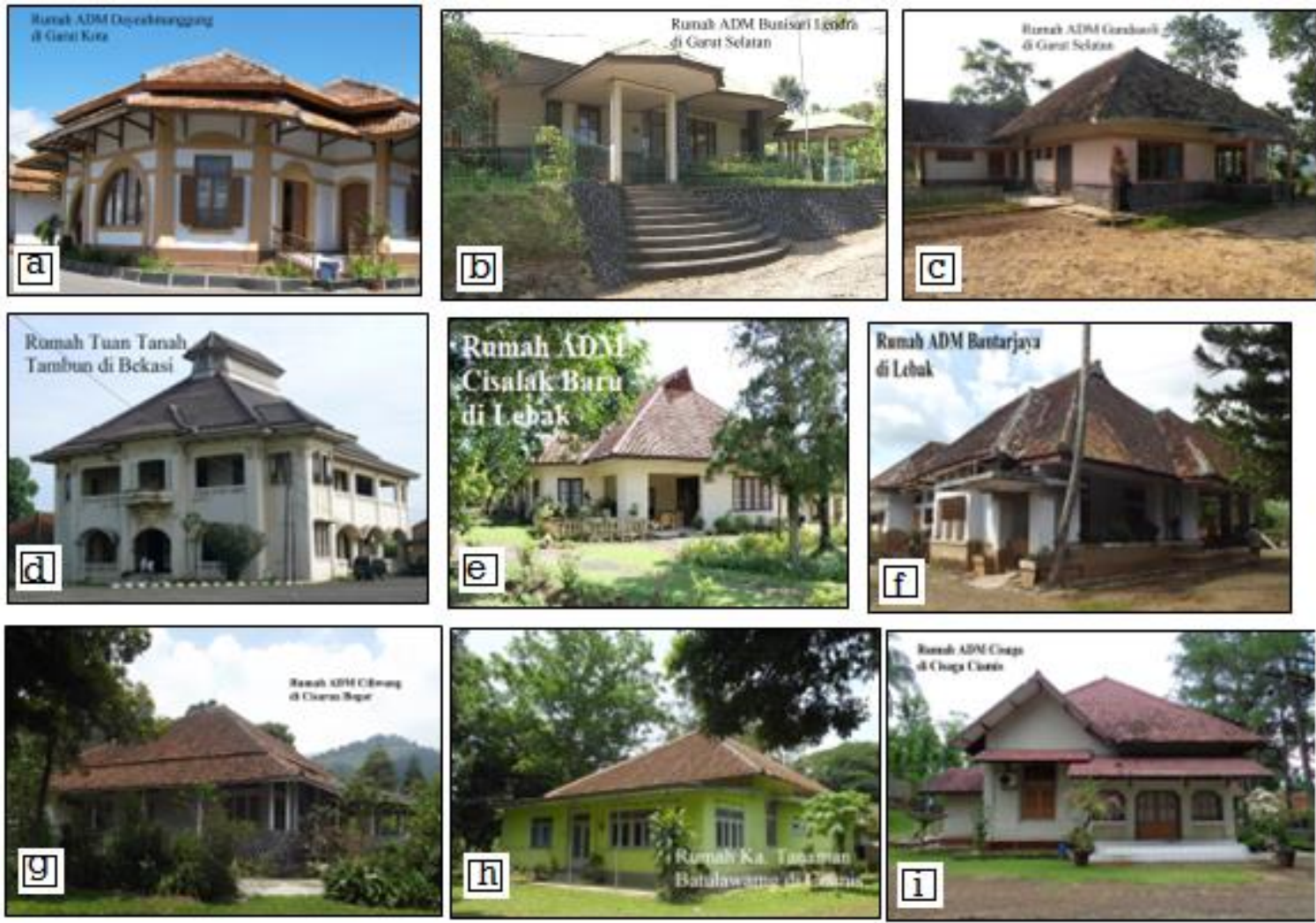

Keterangan gambar

a. Rumah ADM Dayeuhmanggung

b. Rumah ADM Bunisari Lendra

c. Rumah ADM Gandasoli

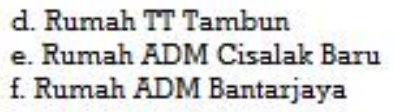

e. Rumah ADM Cisalak Baru f. Rumah ADM Bantarjaya g. Rumah ADM Ciliwung

h. Rumah Ka.Tanaman Batulawang

i. Rumah $A D M$ Cisaga

Gambar 6. Rumah Pejabat Tinggi Perkebunan

(Sumber: Dokumentasi Balai Arkeologi Bandung 2007, 2008, 2009, 2012, 2013, 2014) 
ADM Batulawang (1896), paling muda adalah rumah ADM Ciliwung (1926).

3. Bentuk dasar bangunan persegi panjang dengan variasi adalah menyerupai huruf $\mathrm{L}$ pada rumah ADM Gandasoli dan Kepala Personalia Cikadu, dan segi enam tampak pada rumah ADM Dayeuhmanggung.

4. Langgam art deco dengan konsep arsitektur yang tampil beda, lebih baru, dan lebih modern, tampak pada rumah ADM Dayeumanggung dan ADM Cisaga. seiring dengan perubahan atau pergantian kepemilikan perusahaan perkebunan.

Proses pergantian kepemilikan berjalan sesuai prosedur dan hukum yang berlaku, tetapi biasanya tidak serta merta mengubah bangunan fasilitas perusahaan yang telah ada, bahkan cenderung tidak duilakukan perubahan apa pun. Wujud fisik bangunan dapat dideskripsikan dan dicari makna masa lalunya walaupun berubah kepemilikan. Bangunan-bangunan lama tersebut seolah dapat berbicara dengan sinyal-sinyal
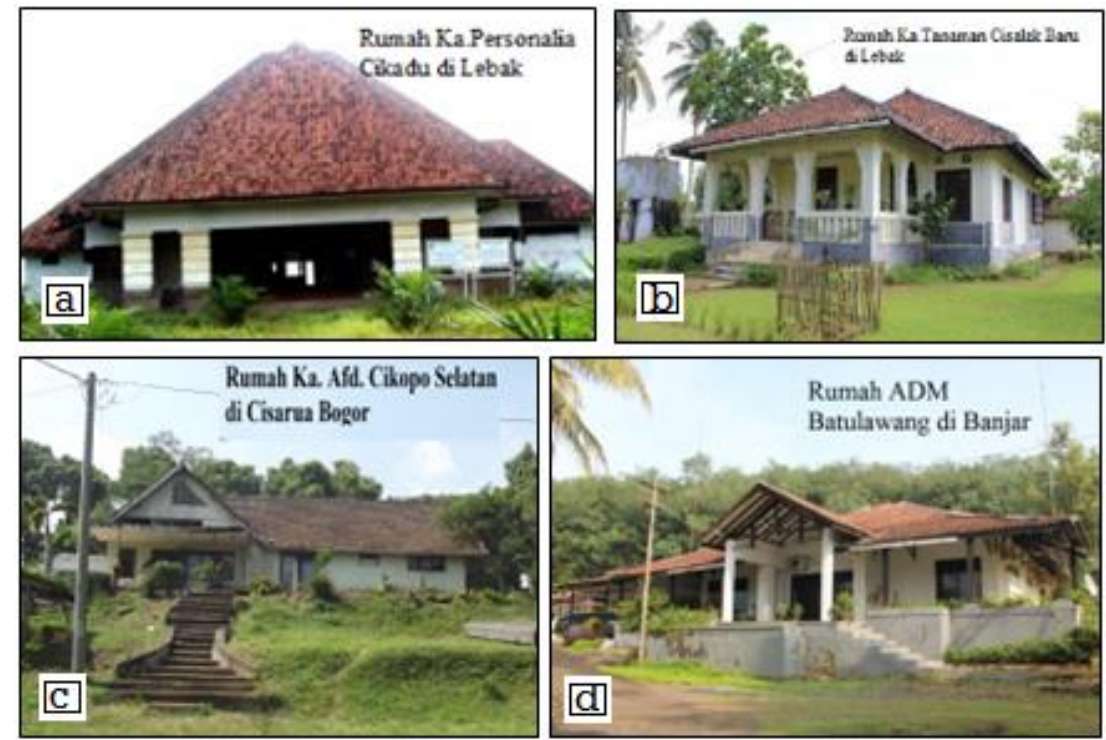

Keterangan gambar :

a. Rumah $\mathrm{Ka}$. Personalia Cikadu

c. Rumah Sinder Afd. Kebun Cikopo Selatan

b. Rumah $\mathrm{Ka}$. Tanaman Cisalak Baru d. Rumah ADM Batulawang

Gambar 7. Rumah Pejabat Tinggi Perkebunan

(Sumber: Dok. Balai Arkeologi Bandung 2012, 2013, 2014)

5. Bangunan dua lantai yang mengadopsi banyak langgam, memuat unsur-unsur gaya art deco, ${ }^{x x i v}$ art nouveau, ${ }^{x \times v}$ de stijl, ${ }^{x \times v i}$ dan Amsterdam school $^{x x v i i}$ adalah rumah Tuan Tanah Tambun.

6. Tiang persegi berbahan kayu sebagai karakter khas Arsitektur Transisi, banyak digunakan pada rumah ADM Ciliwung dengan 38 tiang persegi berbahan kayu.

Rumah-rumah pejabat tinggi perkebunan tersebut merupakan milik tuan tanah (individual) atau didirikan oleh perusahaan swasta asing (organisasi), di antaranya Belanda, joint venture Belanda-Cina, Inggris, joint venture Inggris-Belanda, Perancis, joint venture Perancis-Belanda, Jerman, dan Cina. Dalam perkembangannya kepemilikan rumah bisa berubah dari Eropa ke Cina atau sebaliknya, nonverbal melalui simbol-simbol tertentu. Komunikasi nonverbal tampak melalui wujud fisiknya, sebagai ekspresi jiwa pemiliknya yang berada dalam lingkungan masyarakat, yang telah mengalami pencampuran budaya. Transformasi kondisi sosial politik Pemerintah Kolonial Belanda sangat berpengaruh terhadap perubahan gaya arsitektur. Keadaan tersebut sejalan dengan pernyataan William J O'Malley, bahwa konteks masa lalu tentang sejarah kolonialisme dan imperialisme di Indonesia secara umum, dapat dikatakan sebagai sejarah perkebunan itu sendiri (O’Malley, 1988: 197).

Rumah pejabat tinggi perkebunan umumnya memiliki tata ruang dalam dengan menggunakan konsep Barat dipadu konsep Timur. Sinyal nonverbal dapat memberikan penjelasan yang tampak pada konsep Barat 
yang berorientasi kepada kebudayaan Yunani Klasik. Konsep Barat lebih berorientasi kepada eksistensi diri, mengutamakan kepentingan individual, dan cenderung minim penghayatan transendental. Konsep Timur berupa sejumlah ekspresi sinyal nonverbal, orientasi tampak pada keseimbangan bentuk dan arsitektur, serta lebih mengedepankan harmoni. Hal tersebut dalam manisfestasi arsitektural merupakan dasar pandangan dunia Timur. Konsep Timur juga memperhatikan orientasi arah rumah, arah terbit-terbenam matahari, pergantian musim, pemilihan unsur material, binatang peliharaan, emosi, nilai religi, menunjukkan keserasian manusia dengan tatanan lingkungan alam (Adimiharja dan Purnama Salura, 2004: 19).

Pada umumnya rumah pejabat tinggi perkebunan, memiliki orintasi utara selatan dan timur barat, tampak pada penempatan bagian depan rumah yang mendapat sinar matahari

Tabel 2. Informasi nonverbal pada Rumah Pejabat Tinggi Perkebunan

\begin{tabular}{|c|c|c|c|c|c|}
\hline No & $\begin{array}{l}\text { Rumah Pejabat } \\
\text { Perkebunan }\end{array}$ & $\begin{array}{l}\text { Pemilik/Penghuni/ } \\
\text { Perusahaan }\end{array}$ & $\begin{array}{l}\text { Denah } \\
\text { Bangunan }\end{array}$ & Arsitektur Indis & $\begin{array}{l}\text { Bahan, Teknologi yang } \\
\text { digunakan }\end{array}$ \\
\hline 1. & $\begin{array}{l}\text { ADM } \\
\text { Dayeuhmanggung } \\
\text { (Tjihalimun), } \\
1910 \\
\end{array}$ & $\begin{array}{l}\text { Belanda, Tuan Baron } \\
\text { N.V. Landb. Mij. } \\
\text { "Dajeuh Manggung" } \\
\text { djakarta }\end{array}$ & $\begin{array}{l}\text { Persegi } \\
\text { panjang } \\
\text { (segi enam) }\end{array}$ & Transisi/Art Deco & $\begin{array}{l}\text { Batu bata, plester semen; } \\
\text { konstruksi kayu, pondasi } \\
\text { massif, ditinggikan dari } \\
\text { permukaan tanah }\end{array}$ \\
\hline 2. & $\begin{array}{l}\text { ADM Bunisari } \\
\text { Lendra, } \\
1910\end{array}$ & $\begin{array}{l}\text { Belanda, N.V. Cult. } \\
\text { Industri en Hdl. Mij. } \\
\text { "Pirelli-Java" Garut }\end{array}$ & $\begin{array}{l}\text { Persegi } \\
\text { panjang }\end{array}$ & Transisi & $\begin{array}{l}\text { Batu bata, batu kali, plester } \\
\text { semen, konstruksi kayu, } \\
\text { pondasi massif, ditinggikan } \\
\text { dari tanah }\end{array}$ \\
\hline 3. & $\begin{array}{l}\text { ADM Gandasoli } \\
\text { (Tjisompet), } 1910\end{array}$ & $\begin{array}{l}\text { Belanda, Landb. Mij. } \\
\text { Preanger } \\
\text { Regentschappen, 's } \\
\text { Gravenhage) }\end{array}$ & $\begin{array}{l}\text { Persegi } \\
\text { panjang } \\
\text { (Leter L) }\end{array}$ & Transisi & $\begin{array}{l}\text { Batu bata \& batu bata, plester } \\
\text { semen, konstruksi kayu, } \\
\text { pondasi massif. }\end{array}$ \\
\hline 4. & $\begin{array}{l}\text { TT Tambun, } \\
1906,1910,1925\end{array}$ & $\begin{array}{l}\text { Cina, Khouw Tjeng Kie, } \\
\text { Luitenant der Chinezen, } \\
\text { N.V. Hdl., Bouw en Cult. } \\
\text { Mij. Tiam Ki Djakarta }\end{array}$ & $\begin{array}{l}\text { Persegi } \\
\text { panjang }\end{array}$ & $\begin{array}{l}\text { Transisi/Art Deco, } \\
\text { Art Nouveau, De } \\
\text { Stijl, Amstrerdam } \\
\text { School, }\end{array}$ & $\begin{array}{l}\text { Batu bata, plester semen, } \\
\text { konstruksi kayu, pondasi } \\
\text { massif, ditinggikan dari } \\
\text { permukaan tanah. }\end{array}$ \\
\hline 5. & $\begin{array}{l}\text { ADM Cisalak Baru, } \\
1931\end{array}$ & $\begin{array}{l}\text { Belanda, NV Cultur Mij } \\
\text { Nieuw Tjisalak } \\
\text { Antwerpen }\end{array}$ & $\begin{array}{l}\text { Persegi } \\
\text { panjang }\end{array}$ & Hindia Baru & $\begin{array}{l}\text { Batu bata, batu kali, plester } \\
\text { semen, konstruksi kayu, } \\
\text { pondasi massif. }\end{array}$ \\
\hline 6. & $\begin{array}{l}\text { Ka. Tanaman } \\
\text { Cisalak Baru }\end{array}$ & $\begin{array}{l}\text { Belanda, NV Cultur Mij } \\
\text { Nieuw Tjisalak } \\
\text { Antwerpen }\end{array}$ & $\begin{array}{l}\text { Persegi } \\
\text { Panjang }\end{array}$ & Transisi/Art Deco & $\begin{array}{l}\text { Batu bata, batu kali, plester } \\
\text { semen, konstruksi kayu, } \\
\text { pondasi massif, ditinggikan } \\
\text { dari tanah. }\end{array}$ \\
\hline 7. & $\begin{array}{l}\text { Ka. Personalia } \\
\text { Cikadu } \\
\text { (Residentie Emploje } \\
\text { van Tjikadoe) } \\
\end{array}$ & $\begin{array}{l}\text { Belanda, N.V. Tjikadoe } \\
\text { Rubber Plantage Mij. } \\
\text { Amsterdam }\end{array}$ & $\begin{array}{l}\text { Persegi } \\
\text { Panjang } \\
\text { (Leter L) }\end{array}$ & Transisi/Art Deco & $\begin{array}{l}\text { Batu bata, batu kali, plester } \\
\text { semen, konstruksi kayu, } \\
\text { pondasi massif, ditinggikan } \\
\text { dari tanah. }\end{array}$ \\
\hline 8. & $\begin{array}{l}\text { ADM } \\
\text { Bantarjaya,1910 }\end{array}$ & $\begin{array}{l}\text { Belanda, } N V \\
\text { Bantamsche Plantagen } \\
\text { Mij Antwerpen }\end{array}$ & $\begin{array}{l}\text { Persegi } \\
\text { panjang }\end{array}$ & Hindia Baru & $\begin{array}{l}\text { Batu bata, batu kali; plester } \\
\text { semen, konstruksi kayu, } \\
\text { pondasi massif. }\end{array}$ \\
\hline 9. & $\begin{array}{l}\text { ADM Ciliwung, } \\
1926\end{array}$ & $\begin{array}{l}\text { Cina, N.V. Rolley Davis/ } \\
\text { N.V. Ban Him/ N.V. Cult. } \\
\text { en Handel Mij Tjiliwung- } \\
\text { Londen }\end{array}$ & $\begin{array}{l}\text { Persegi } \\
\text { panjang }\end{array}$ & Transisi & $\begin{array}{l}\text { Batu bata, batu kali, kayu; } \\
\text { plester semen, konstruksi } \\
\text { kayu, pondasi massif, } \\
\text { ditinggikan dari tanah. }\end{array}$ \\
\hline 10. & $\begin{array}{l}\text { Ka.Afd.Kebun } \\
\text { cikopo Selatan, } \\
1912\end{array}$ & $\begin{array}{l}\text { Jerman, Belnada: NV } \\
\text { Cultur Mij. Tjikopo Zuid/ } \\
\text { N.V.Tiedemant E. Van } \\
\text { Kerchem }\end{array}$ & $\begin{array}{l}\text { Persegi } \\
\text { panjang }\end{array}$ & Hindia Baru & $\begin{array}{l}\text { Batu bata, kayu, plester } \\
\text { semen, konstruksi kayu, } \\
\text { pondasi massif, ditinggikan } \\
\text { dari permukaan tanah. }\end{array}$ \\
\hline 11. & ADM Cisaga, 1908 & $\begin{array}{l}\text { Perancis-Belanda, } \\
\text { Societe France } \\
\text { Neerlandaice de Cultur } \\
\text { \& de Commerce Paris }\end{array}$ & $\begin{array}{l}\text { Persegi } \\
\text { panjang }\end{array}$ & Transisi/Art Deco & $\begin{array}{l}\text { Batu bata, kayu, plester } \\
\text { semen, konstruksi kayu, } \\
\text { pondasi massif, ditinggikan } \\
\text { dari permukaan tanah. }\end{array}$ \\
\hline 12. & $\begin{array}{l}\text { Wkl ADM } \\
\text { Batulawang/1908 }\end{array}$ & $\begin{array}{l}\text { Perancis-Belanda, } \\
\text { Societe France } \\
\text { Neerlandaice de Cultur } \\
\text { \& de Commerce Paris }\end{array}$ & $\begin{array}{l}\text { Persegi } \\
\text { panjang }\end{array}$ & Transisi & $\begin{array}{l}\text { Baja, kayu, kaca, sambungan } \\
\text { mur \& baud pd lempengan } \\
\text { baja, lepa semen, konstruksi } \\
\text { baja }\end{array}$ \\
\hline 13. & $\begin{array}{l}\text { ADM Batu Lawang } \\
\text { Banjar, } 1896\end{array}$ & $\begin{array}{l}\text { Dr. Stoll/Belanda, } \\
\text { N.V. Java Caoutchouc } \\
\text { Co te Amsterdam }\end{array}$ & $\begin{array}{l}\text { Persegi } \\
\text { panjang }\end{array}$ & Transisi & $\begin{array}{l}\text { Batu bata, kayu, plester } \\
\text { semen, pondasi massif, } \\
\text { ditinggikan dari tanah }\end{array}$ \\
\hline
\end{tabular}


pagi. Sementara sinar matahari di siang hari akan mengenai bagian belakang rumah. Untuk bangunan rumah dengan pintu utama (depan rumah) di bagian dinding samping, pintu utama menghadap ke arah barat untuk mendapat kehangatan sinar matahari pagi, serta menghindarkan teriknya sinar matahari di siang dan sore hari.

Perpaduan konsep Barat dan Timur tersebut termanifestasikan dalam wujud rumah, yang tampak pada tata ruang dalam rumah pejabat tinggi perkebunan, seperti tergambarkan pada beberapa denah rumah (gambar 4 dan 5). Rumah bagian dalam dibagi menjadi beberapa ruang sesuai fungsi dan kebutuhannya, dengan memperhatikan sirkulasi udara dan cahaya di dalam tiap-tiap ruangan. Kebutuhan udara bersih dan penerangan di dalam ruangan dapat dipenuhi dengan adanya jendela dan ventilasi pada bagian-bagian dinding pada tiap-tiap ruangan yang terbuka ke udara luar. Kebutuhan tersebut dapat terpenuhi dengan adanya halaman di sekeliling bangunan dan adanya jarak yang cukup, sehingga udara bebas dari laur bisa masuk dengan lancar. Halaman rumah keliling ini juga dilengkapi dengan taman pohon-pohon rendah (pohon hias), dan pohonpohon tinggi yang rindang sebagai peneduh.

Wujud adanya akulturasi tampak juga pada penggunaan bahan-bahan bangunan dan teknologi yang digunakan. Bahan-bahan bangunan sebagian besar diambil dari lingkungan sekitar. Seperti bahan untuk dinding menggunakan bata merah dan batu kali, rangka atap dan kusen pintu jendela terbuat dari kayu yang berasal dari pohon-pohon kayu hutan tropis, penutup atap berbahan genteng dari tanah liat yang diproduksi lokal. Selain itu, ada juga rumah pejabat tinggi yang menggunakan bahan dinding diimpor dari luar negeri, yaitu bahan lempengan besi baja dari Belgia. Teknik yang digunakan menggunakan teknik sambung mur dan baud untuk menyatukan lempenganlempengan besi baja persegi berukuran sekitar 1 meter ${ }^{2}$. Lempengan besi baja yang telah bersatu membentuk dinding rumah, kemudian diplester semen dan dicat. Bahan dinding unik ini ditemukan pada rumah Kepala Tanaman Batulawang di Cisaga Ciamis (bekas bangunan Mess Perkebunan Cisaga).

Pembangunan rumah pejabat tinggi perkebunan tidak sembarang dilakukan, tetapi direncanakan dengan matang dan mendapat pengawasan ketat dalam pelaksanaannya. Konsep rumah ditetapkan, mulai dari penentuan skala, struktur dan konstruksi, ketinggian, penggunaan bahan bangunan dan ornament atau dekorasi, serta hal-hal detail lainnya. Pemilik atau pengelola perkebunan sebagai pejabat tinggi langsung turun tangan dalam menentukan konsep dan rancangannya, serta pengawasan langsung di lapangan. Pola pikir Barat melekat kuat dalam setiap konsep yang ditetapkan, tetapi adaptasi dengan lingkungan sekitar pun menjadi bahan pertimbangan penting. Rumahrumah besar dan megah, pintu jendela tinggi dan besar, plafon dan atap tinggi, merupakan beberapa unsur arsitektur lokal dipadu dengan konstruksi kayu dengan teknik modern Barat (tabel 2). Keadaan ini menunjukkan ada perhatian khusus untuk golongan tertentu dalam pembuatan rumah tinggalnya, mempertegas perbedaan status sosial dan menentukan perbedaan dalam pembangunan rumah tinggal perkebunan tersebut. Struktur sosial telah melahirkan nilai-nilai kolonial. Pejabat tinggi perkebunan mendirikan rumah tinggalnya dengan gaya arsitektur tertentu, memperhatikan kenyamanan dan kelayakan hidup, kesehatan para penghuninya, dan lain-lain adalah suatu kepastian yang harus dilakukan. Sementara itu, para pekerja atau buruh kebun membangun rumah tinggal sebatas pemenuhan kebutuhan dasar, hanya fungsi perlindungan dari sengatan sinar matahari dan air hujan.

Adanya saling pengaruh antara kebijakan politik dan ekonomi pemerintah dengan perkembangan trend gaya arsitektur, menjadi sangat kentara. Perkembangan perkebunan juga memiliki peranan penting dalam menentukan kebijakan Pemerintah Hindia Belanda, dan memberi corak baru dalam kehidupan masyarakat Hindia Belanda secara umum. Letak kebun yang jauh berada di pedalaman merupakan enclave tersendiri, melahirkan budaya perkebunan yang khas dengan nilainilai kolonialnya yang masih bertahan sampai sekarang. Pada sekarang ini di lingkungan perkebunan, nilai-nilai kolonial tersebut akan tampak pada tata letak bangunan dalam permukiman emplasemen perkebunan (gambar 2 dan 3), bentuk dan gaya arsitektur (gambar 4, 5, dan 6; tabel 1, 2, dan 3), serta penggunaan istilah-istilah lama yang telah menjadi istilah Indonesia, seperti administratur, sinder afdeling, emplasemen, dan sebagainya. rumah- 
rumah kolonial di perkebunan berada dalam tatanan khusus dengan jarak-jarak tertentu. Jarak antar bangunan ini menjadi penting karena menentukan fungsi bangunan dan status sosial penghuninya. Hubungan antar bangunan menjadi satu komunikasi dalam ruang.

Komunikasi nonverbal rumah pejabat tinggi perkebunan sebagai komunikasi dalam ruang/komunikasi spasial (proxemics) tampak pada jarak antar bangunan. Bangunan rumah pejabat tinggi perkebunan umumnya terpisah dengan bangunan-bangunan perkebunsn lainnya (gambar 8). Jarak antar bangunan dalam permukiman emplasemen perkebunan, menjadi sinyal nonverbal yang memberi informasi jarak antar etnis dan golongan, yang mendasari interaksi antar status sosial berbeda. Ada 4 kategori jarak antar bangunan yang menjadi indikasi adanya jarak sosial dalam masyarakat perkebunan, baik secara pribadi/individu maupun golongan/kelompok sosial, yaitu: (1) Jarak intim (0-45 m), (2) jarak pribadi (45-120 m), (3) jarak sosial (120-360 m), dan (4) jarak publik (360-750 m).

Dalam tulisan ini diambil salah satu contoh kasus untuk menggambarkan tentang komunikasi dalam ruang atau proxemics tersebut, yaitu rumah ADM Cisaga sebagai sentral bangunan (gambar 3). Keempat kategori jarak antar bangunan tersebut, yaitu: (1) Jarak rumah ADM dengan rumah Kepala Tanaman sebagai jarak intim; (2) jarak rumah ADM dengan perumahan karyawan sebagai jarak sosial; (3) jarak rumah ADM dengan kantor induk administrasi sebagai jarak sosial sekaligus pribadi; dan (4) jarak rumah ADM dengan pabrik karet sebagai jarak sosial dan jarak publik (Nuralia, 2016b: 230).

Jarak rumah ADM dengan rumah Kepala Tanaman sangat dekat, sekitar \pm 1 meter, sehingga termasuk kategori intim. Hal ini menunjukkan bahwa interkasi di antara mereka sangat intens dan berupa hubungan personal dan formal yang sejajar atau setingkat kedudukannya sebagai pejabat tinggi perkebunan pada lapisan atau kelas sosial atas. Sementara itu, jarak rumah ADM dengan perumahan karyawan/buruh perkebunan adalah jarak sosial dan jarak publik. Dalam hal ini interaksi di antara mereka tidak dekat dan tidak ada dalam tataran sejajar. Status sosial yang berbeda antara pejabat tinggi dan karyawan, antara majikan dan buruh, kelas atas dan kelas bawah, Barat dan Timur, Eropa (Belanda) dan pribumi Indonesia.

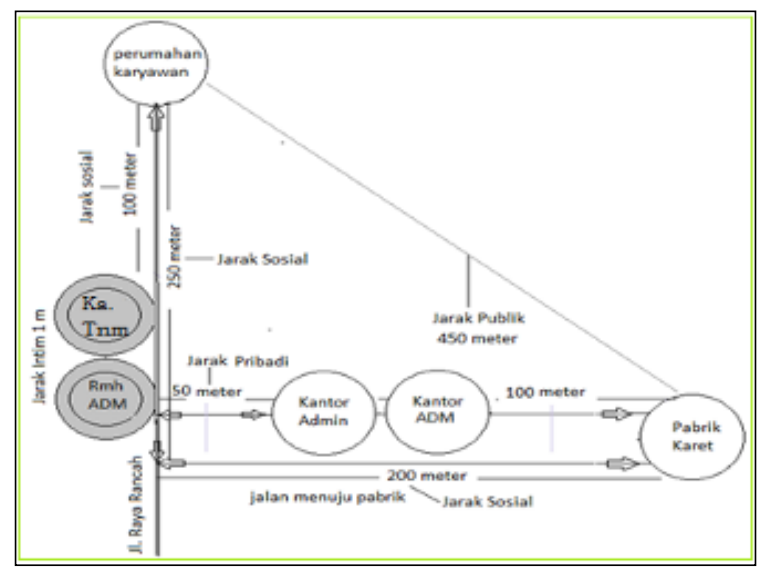

Gambar 8. Ilustrasi Komunikasi Spasial/Proxemics Antar Bangunan Pada Permukiman Emplasemen Perkebunan Cisaga

(Sumber: Nuralia, 2016b: 230)

Adanya jarak tertentu antara rumah ADM Cisaga sebagai sentral bangunan, dengan bangunan-bangunan perkebunan lainnya menunjukkan adanya jarak sosial antar individu dan kelompok sosialnya. Jarak-jarak tersebut merupakan jarak sosial berdasarkan status sosial dan golongan etnis dalam hierarki kekuasaan, pada struktur organisasi perusahaan dan masyarakat perkebunan. Dengan demikian, struktur sosial yang temanifestasikan dalam proxemics melahirkan kode budaya kolonial yang tergambar dalam penataan rumah dan lingkungannya. Dalam kode budaya tersebut terkandung nilai-nilai kebudayaan zaman kolonial Belanda. Kedudukan atau status sosial berbeda akan melahirkan pemisahan dan jarak dalam penempatan dan pendirian bangunan rumah tinggal di lingkungan perkebunan.

\section{KESIMPULAN}

Bangunan rumah pejabat tinggi perkebunan peninggalan zaman Hindia Belanda yang masih ada sampai sekarang, dapat dikaji makna simboliknya dibalik wujud fisik bangunannya. Beberapa bangunan tersebut adalah rumah administratur, wakil administratur (kepala tanaman, kepala personalia), dan kepala afdeling. Rumah-rumah tersebut berada di kota dan kabupaten yang ada di Jawa bagian barat.

Rumah pejabat tinggi perkebunan merupakan sentral bangunan dalam struktur bangunan perkebunan, baik di lokasi maupun di 
luar lokasi perkebunan. Untuk bangunan yang berada jauh dari lokasi perkebunan secara fisik tidak berasosiasi dengan bangunan-bangunan perkebunan lainnya, tetapi secara nonfisik tetap menjadi sentral bangunan dengan melihatnya dari perspektif status dan jabatannya.

Makna simbolik tersebut melahirkan struktur sosial khas perkebunan, yang menjadi pola umum dalam struktur masyarakat perkebunan. Struktur tersebut melahirkan stratifikasi sosial khas masyarakat perkebunan berdasarkan pekerjaan dan ras/etnis, terbagi ke dalam tiga golongan sosial, yaitu atas, menengah, dan bawah. Golongan atas dengan status sosial tinggi terdiri dari Administrtur atau Tuan Tanah perkebunan, wakil administratur, dan kepala afdeeling kebun. Golongan menengah adalah para pengawas atau mandor kolonial, sedangkan golongan bawah adalah para mandor pribumi dan buruh/kuli.

Berdasarkan wujud fisiknya, rumah pejabat tinggi perkebunan terbagi menjadi tiga pola bagian bangunan dan dua pola tata ruang dalam rumah tinggal. Pola-pola tersebut sebagai kode budaya kolonial yang mengandung nilainilai kebudayaan kolonial, yaitu pejabat tinggi perkebunan memiliki kekuasaan sangat besar dalam masyarakat perkebunan yang multietnis.

Pada masa sekarang ini struktur masyarakat perkebunan masih menjalankan pola lama, yang berbeda adalah orang-orang yang menempati posisi atas dan menengah, yaitu orang-orang Indonesia asli. Kode budaya kolonial yang mengandung nilai-nilai kebudayaan kolonial Belanda pun masih tampak, terutama dalam tata letak bangunan dan istilah-istilah yang digunakan di lingkungan perkebunan.

\section{Ucapan Terima Kasih}

Penulis menyampaikan terimakasih kepada Administratur, Kepala Tanaman/Wakil Administratur, Kepala Afdeling, para karyawan perkebunan, serta kepala bagian kebudayaan, staf kecamatan dan desa di lokasi setempat, yang telah membantu dalam proses pencarian data. Juga terimakasih untuk teman-teman satu tim Balai Arkeologi Bandung (Jawa Barat), yang telah memberikan tenaga dan pikirannya selama proses pencarian data di lapangan dan ketika penulisan laporan dilakukan. Juga kepada semua pihak yang tidak dapat disebutkan satu per satu, segala bantuan dan dukungannya semoga menjadi amal baik yang akan mendapat balasan dari Tuhan Yang Maha Esa.

\section{$* * * * *$}

\section{DAFTAR PUSTAKA}

Adimiharja, Kusnaka, \& Purnama Salura. (2004). Arsitektur Dalam Bingkai Kebudayaan. Jakarta: Architecture and Communication.

Boomgaard, Peter. (2004). Anak Jajahan Belanda, Sejarah Sosial dan Ekonomi Jawa 1795-1880. Terjemahan Monique Soesman, Keosalah Soebagyo Toer. Jakarta: KITLV-Jakarta dan Djambatan.

Cassela, Eleanor Conlin. (2005). Social Workers: New Diretions in Industrial Archaeology. In James Symonds (Ed.), Industrial Archaeology: Future Directions (pp. 3-32). Washington DC: Springer Science and Business Media Inc.

Darmodiharjo, Darji. (1995). Pokok-pokok Filsafat Hukum: apa dan bagaimana filsafat hukum Indonesia. Jakarta: Gramedia Pustaka Utama.

Fletcher, Rolland. (1989). The Massages Of Mareial Behaviour: A Preliminary Discussion Of NonVerbal Meaning. In Ian Hodder (Ed.), The Massages Of Things: Material Culture and Symbolic Expression (pp. 33-44). London and New York: Routledge.

Gill, Ronald. (2002). Perumahan Kota Gaya Belanda. Dalam Tjahjono Gunawan (Penyusun). In Karsono H. Saputra et.al. (Ed.) Indonesian Heritage Jilid 6: Arsitektur (pp. 112-113). Jakarta: Buku Antar Bangsa Untuk Grolier Internasional, Inc.

Handinoto. (2010). Arsitektur dan Kota-Kota di Jawa pada Masa Kolonial. Yogyakarta: Graha Ilmu.

Handinoto. (1996). Perkembangan Kota dan Arsitektur Kolonial Belanda di Surabaya 1870-1940. Yogyakarta: Lembaga Penelitian dan Pengabdian Kepada Masyarakat Universitas Kristen Petra Surabaya Andi Offset.

Hodder, Ian. (2013). The Contextual Analysis Of Symbolic Meanings. In Susan M. Pearce (Ed.), Interpreting Objects and Collections. London and New York: Routledge.

Ismet. (1970). Daftar Tanah-Tanah Perkebunan di Indonesia (The List of Estates Throughout Indonesia). Bandung: Biro Sinar C.V.

Kartodirdjo, Sartono, \& Djoko Surjo. (1991). Sejarah Perkebunan di Indonesia, Kajian Sosial Ekonomi. Yogyakarta: Aditya Media. 
Littlejohn, Stephen, \& Foss. (2008). Theories of Human Communication, ( $9^{\text {th }}$ Ed.). Belmont: Thomson Wadsworth.

Nuralia, Lia. (2009a). Gedung Juang '45 (Gedung tinggi) Bekasi: Mengkaji Jejak Sejarah dan Arkeologi Periode Kolonial. In Agus Aris Munandar (Ed.), Widyamala, Arkeoklogi dan Masyarakat (pp. 92-112). Jatinagor: AlQaprint.

Nuralia, Lia. (2009b). Bangunan Pabrik Kakao dan Kantor Afdeling Perkebunan Bunisari Lendra: Bangunan Kuna di Garut Selatan dalam Perspektif Sejarah dan Arkeologi. In Supratikno Rahardjo (Ed.), Arkeologi Pengelolaan Sumber Daya Budaya (pp. 75-94). Jatinagor: Al-Qaprint.

Nuralia, Lia, \& Nanang Saptono. (2012). Laporan penelitian: Bangunan Kolonial di Lokasi Perkebunan Cisalak Baru-Bantarjaya dan Sekitarnya, Kabupaten Lebak, Provinsi Banten. Bandung: Kementerian Kebudayaan dan Pariwisata, Badan Pengembangan Sumber Daya, Balai Arkeologi Bandung.

Nuralia, Lia. (2013a). Jejak-Jejak Akivitas Budaya Kawasan Perkebunan Cisalak Baru-Bantarjaya, Kabupaten Lebak. Purbawidya, 2(1), 50-66.

Nuralia, Lia. (2013b). Menara Loji dan Makam Mimosa: Jejak Sejarah Bekas Kawasan Perkebunan Jatinangor Abad XIX-XX. Prosiding Seminar Nasional dalam Rangka 100 Tahun Purbakala 2013, (pp. 38-49).

Nuralia, Lia, et. al. (2013c). Laporan penelitian: Bangunan Kolonial Perkebunan Gunung Mas, Kabupaten Bogor dan Sekitarnya, Provinsi Jawa Barat. Bandung: Kementerian Pendidikan dan Kebudayaan, Pusat Arkeologi Nasional, Balai Arkeologi Bandung. Tidak terbit.

Nuralia, Lia. (2014a). Arsitektur Transisi pada Rumah Dinas Administratur Perkebunan Teh Ciliwung di Cisarua Kabupaten Bogor. Makalah. Prosiding Seminar Nasional Arkeologi, (pp. 107-117).

Nuralia, Lia, et. al. (2014b). Laporan penelitian: Bangunan Kolonial Perkebunan Batulawang di Kabupaten Ciamis dan Sekitarnya, Provinsi Jawa Barat. Bandung: Kementerian Pendidikan dan Kebudayaan, Pusat Penelitian Arkeologi Nasional, Balai Arkeologi Bandung. Tidak terbit.

Nuralia, Lia. (2015). Peran Elite Pribumi dalam Eksploitasi Kapitalisme Kolonial: Komparasi Antara Prasasti dan Arsip. Purbawidya, 4(1), 39-54.

Nuralia, Lia. (2016a). Situs Perkebunan Cisaga 1908-1972: Kajian Arkeologi Industri tentang Kode Budaya Kolonial. Universitas Indonesia.
Nuralia, Lia. (2016b). Permukiman Emplasemen Perkebunan Batulawang di Afdeling Lemahneundeut di Ciamis, Jawa Barat. Purbawidya, 5(1), 29-48.

Niel, Robert van. (1984). Munculnya Elit Modern Indonesia. Zahara Deliar Noer, \& Bur Rasuanto (Ed.). Jakarta: Pustaka Jaya.

O’Malley, William J. (1988). Perkebunan 18301940: Ikhtisar. In Anne Booth, William J. O’Malley, \& Anna Weidermann (Ed.), Sejarah Ekonomi Indonesia. Jakarta: LP3ES.

Passchier, Cor. (2002). Kota Taman dan Bungalau Pinggiran Kota. In Tjahjono Gunawan (Ed.), Indonesian Heritage Jilid 6: Arsitektur (pp. 124-125). Jakarta: Buku Antar Bangsa untuk Grolier Internasional, Inc.

Pearce, Susan M. (Ed.). (2003). Interpreting Objects and Collections. London and New York: Routledge.

Pranoto, Suhartono W. (2010). Jawa Bandit-Bandit Pedesaan, Sutdi Historis 1850-1942. Yogyakarta: Graha Ilmu.

Sukiman, Djoko. (2000). Kebudayaan Indis dan Gaya Hidup Masyarakat Pendukungnya di Jawa (Abad XVIII - Medio Abad XX). Jogjakarta: Bentang Budaya.

Sumalyo, Yulianto. (2003). Arsitektur Klasik Eropa. Yogyakarta: Gadjah Mada University Press.

Sumalyo, Yulianto. (1995). Arsitektur Kolonial Belanda di Indonesia. Yogyakarta: Gadjah Mada University Press.

Sukada, Budi A. (2002). Kemunculan Gaya Hindia Baru. In Tjahjono Gunawan (Ed.), Indonesian Heritage Jilid 6: Arsitektur (pp. 120-121). Jakarta: Buku Antar Bangsa Untuk Grolier Internasional, Inc.

Tim Peneliti. (2009). Laporan penelitian: Permukiman Puncak-Puncak Peradaban Awal Masehi Sampai Masa Kolonial di Kabupaten Karawang, Purwakarta, Bekasi, Provinsi Jawa Barat. Bandung: Balai Arkeologi Bandung. Tidak terbit.

Tim Peneliti. (2008). Laporan penelitian: BangunanBangunan Kolonial di Kabupaten Garut, Provinsi Jawa Barat. Bandung: Balai Arkeologi Bandung. Tidak terbit.

Tim Peneliti. (2007). Laporan penelitian: BangunanBangunan Kolonial di Kota Garut, Provinsi Jawa Barat. Bandung: Balai Arkeologi Bandung. Tidak terbit.

Wulan, Roro Retno. (2015). Komuniskasi NonVerbal Bangunan Kolonial di Perkebunan Teh Jawa Barat. Jurnal Sosioteknologi, 14(3), 221-236. 


\section{ENDNOTES}

' Perkebunan merupakan sistem usaha besar bagian dari sistem perekonomian pertanian komersial dan kapitalistik. Usaha pertanian dalam skala besar dan kompleks, padat modal, lahan luas, tenaga dan pembagian kerja besar dan rinci, tenaga kerja upahan, struktur atau organisasi kerja rapih, teknologi modern, spesialisasi, system administrasi dan birokrasi, tanaman komersial untuk komoditi ekspor di pasar dunia. Berbeda dengan sistem kebun diwujudkan dalam usaha kecil, pelengkap/tambahan dari pertanian pokok (pangan), tidak padat modal, lahan terbatas, anggota keluarga tenaga kerja, berorientasi kebutuhan subsisten (Kartodirdjo dan Djoko Surjo, 1991: 4).

ii Undang-Undang Agraria 1870 lahir bersamaan dengan Undang-Undang Gula 1870. UndangUndang Gula (21 Juli, Staatsblad 136) menyatakan berakhirnya Sistem Tanam Paksa, sedangkan Undang-Undang Agraria (9 April 1870, Staatsblad 55) dan Dekrit Agraria (Koninklijk Besluit 20 Juli 1870, Staatsblad 118) memudahkan hibah tanah jangka panjang bagi perusahaan Eropa, dan berisikan ketentuan pemilikan tanah pribumi lebih sesuai dengan hak atas tanah pra-1800 (Boomgaard, 2004: 64) (Nuralia, 2016: 3).

iii Arsitektur kolonial dalam tulisan ini adalah arsitektur Modern Eropa yang telah beradaptasi dengan lingkungan setempat. Arsitektur Modern Eropa adalah arsitektur Neo-Klasik berupa pengulangan gaya Yunani-Romawi Kuno, terutama penggunaan kolom atau order masa Yunani sebagai struktur sekaligus dekorasi, dengan denah bangunan sebagian besar simetris. Arsitektur Modern Eropa merupakan konsep arsitektur baru setelah melewati masa revolusi industri di Eropa (Inggris) pada abad ke-19 (Sumalyo, 1995: 4, dan Sumalyo 2003: 479, 531). Arsitektur Modern Eropa yang beradaptasi dengan lingkungan setempat tampak adanya unsurunsur arsitektur lokal dalam elemen-elemen bangunan, bahan, dan gaya/bentuk bangunannya.

iv Lihat juga dalam Nuralia, 2016: 17

$\checkmark$ Kemenangan kaum liberal di negeri Belanda memicu pertumbuhan kapitalisme dan industrialism, mencorong ekspansi ke daerah jajahan berupa kapitalisme finansial. Sejak tahun 1870 kebutuhan investasi modal mencari penyalurannya ke perusahaan perkebunan. Undang-undang Agraria 1870 menetapkan tata guna tanah sebagai berikut.

1. Tanah milik rakyat tidak dapat diperjualbelikan kepada nonpribumi;

2. Tanah domain pemerintah sampai seluas sampai seluas 10 bau dapat dibeli oleh nonpribumi untuk keperluan bangunan perusahaan;
3. Tanah domain pemerintah yang lebih luas dari itu kepada nonpribumi diberi kesempatan memiliki hak guna, yaitu:

a. Sebagai tanah dan hak membangun (recht van opstal, disingkat RVO),

b. Tanah sebagai erfpacht (hak sewa serta hak mewariskan) untuk jangka waktu 75 tahun.

(Kartodirdjo dan Djoko Surjo, 1991: 80).

vi Rumah Administratur Dayeuhmanggung adalah Kantor Dinas Pariwisata dan Kebudayaan Kabupaten Garut, di Jalan Ciledug No. 120, Kecamatan Garut Kota, Kabupaten Garut. Pada awalnya sebagai rumah tinggal Tuan Baron (ADM Dayeuhamanggung) dan keluarga. Setelah diambil alih Negara Kesatuan Republik Indonesia 1958, pernah difungsikan sebagai kantor bupati dan kantor inspektorat (Nuralia, 2007: 34).

vii Rumah Administratur Gandasoli adalah Kantor Besama Afdeling Pasir Sela, Cisompet, dan Cisarua, Perkebunan Bunisari Lendra, di Kampung Cisondang, Desa Cisompet, Kecamatan Cisompet, Kabupaten Garut (Nuralia, 2009a: 85).

viii Rumah Tuan Tanah Tambun adalah Gedung Tinggi/Gedung Juang 45 di Jln Sultan Hasanudin No. 5, Kecamatan Tambun Selatan, Kabupaten Bekasi. Berupa komplek bangunan terdiri dari 6 bangunan. Satu bangunan inti yang dibahas sebagai tempat tinggal administratur dan keluarga (Nuralia, 2009a: 96).

ix Rumah Administratur Perkebunan Cisalak Baru adalah Rumah Administratur Perkebunan Cisalak Baru-Bantarjaya setelah berada dalam satu manajemen dengan Perkebunan Bantarjaya. Berada dalam kawasan permukiman emplasemen perkebunan di Jalan Raya Cipanas No. 7, Desa Cimangeunteung, Kecamatan Rangkasbitung, Kabupaten Lebak (Nuralia, 2013: 54).

${ }^{x}$ Rumah Kepala Tanaman Perkebunan Cisalak Baru adalah Rumah Kepala Tanaman Perkebunan Cisalak Baru-Bantarjaya, kawasan permukiman emplasemen perkebunan di Jalan Raya Cipanas No. 7, Desa Cimangeunteung, Kecamatan Rangkasbitung, Kabupaten Lebak (Nuralia, 2013: 54).

xi Rumah Dinas Kepala Personalia Perkebunan Cikadu adalah bangunan yang sudah tidak difungsikan lagi di kebun Afdeling Cisalak BaruBantarjaya (Nuralia dan Nanang Saptono, 2012).

xii Rumah Administratur Bantarjaya adalah Rumah Dinas Kepala Afdeling IV Perkebunan Cisalak Baru-Bantarjaya, di lokasi kebun dalam kawasan emplasemen kantor afdeling III dan IV, Kampung Bantarjaya, Desa Jayamanik, Kecamatan Cimarga, Kabupaten Lebak (Nuralia, 2013: 56).

xiii Rumah Administratur Perkebunan Ciliwung adalah rumah tinggal pribadi Ibu Yurianti Wijaya dan keluarga, sebagai istri dari salah seorang bekas 
administratur Perkebunan Ciliwung zaman Belanda. Berada di lokasi kebun Afdeling Ciliwung A (Rawa Gede), No. 16, RT/RW 03/04, Kampung Pondok Rawa, Dusun II, Desa Tugu Utara, Kecamatan Cisarua, Kabupaten Bogor (Nuralia, 2014a: 112)

xiv Rumah Kepala Afdeling Kebun Cikopo Selatan Perkebunan Gunung Mas, di Desa Citeko, Kecamatan Cisarua Kabupaten Bogor, Provinsi Jawa Barat (Nuralia dkk, 2013c).

${ }^{x v}$ Rumah Administratur Perkebunan Cisaga adalah Mess Perkebunan Batulawang di Cisaga. Pernah difungsikan sebagai Rumah Dinas Kepala Tanaman Perkebunan Batulawang, di Kecamatan Cisaga, Kabupaten Ciamis, Jawa Barat (Nuralia dkk, 2014b). xvi Rumah Kepala Tanaman Perkebunan Batulawang, pernah difungsikan sebagai Mess Perkebunan Cisaga, di Kecamatan Cisaga, Kabupaten Ciamis, Provinsi Jawa Barat (Nuralia dkk, 2014b).

xvii Rumah Administratur Perkebunan Batulawang adalah Rumah Administratur Perkebunan Batu Lawang Banjar (Batulawang lama), di Emplasemen Ciaren, Desa Batulawang, Kecamatan Pataruman, Kota Banjar, Jawa Barat (Nuralia dkk, 2014b).

xviii Pada abad ke-18 banyak didirikan rumah-rumah besar dan megah disebut landhuisen, di Batavia dan Surabaya. Rumah mewah tropis bergaya mirip rumah Jawa dengan atap joglo mirip pendopo, teras keliling melindungi dari sinar matahari langsung dan tampias air hujan. Banyaknya bukaan sebagai ventilasi silang (cross ventilation), kolom-kolom penyangga atap tinggi. Rumah-rumah tersebut disebut Indies Style Country House atau Transitional Dutch Indies Country House. Juga merupakan Typical denah rumah gaya Indische Empire, ciri khas teras depan dan belakang sebagai bagian penting. Model arsitektur Eropa (Perancis) terkenal dengan sebagi gaya Empire dipilih Daendels karena tampak depannya terkesan sebagai gaya neoklasik monumental, pencerminan kewibawaan pemerintah Hindia Belanda (Handinoto, 2010: 50-51).

xix Arsitektur Transisi adalah arsitektur peralihan dari Indische Empire (abad ke-19) menuju Indo European (abad ke-20) atau perpaduan keduanya. Ciri-ciri menonjol: denah bangunan simetri penuh, teras depan (voor galerij), teras samping, dan teras belakang (achter galerij), bangunan tambahan di belakang, bentuk atap pelana dan perisai (atap rumah kampung dan limasan), tiang/kolom persegi berbahan kayu, sistem konstruksi memamaki dinding pemikul dengan gevel-gevel depan yang mencolok (Handinoto, 2010: 44, 85, 145-147).

$\mathrm{xx}$ Bagi karyawan perkebunan yang berasal dari penduduk kampung di sekitar lokasi perkebunan, biasanya tetap tinggal di kampungnya bersama keluarga besar. Mereka berangkat pagi menjadi buruh kebun dan pulang di siang atau sore harinya.
Perumahan buruh yang disediakan perusahaan tidak ditempatinya (wawacara dengan bapak Sjapei, pensiunan buruh Pabrik Cisaga, Maret 2016).

${ }^{x \times i}$ Permukiman perkebunan yang jauh dari dunia luar atau berada di tengah-tengah kebun, menjadi permukiman yang kompleks terdiri atas unsur-unsur sosial ekonomis yang berbeda, tetapi tidak terpisahkan dalam kaitan kerja atau hubungan sistem produksi. Situasi ini menimbulkan kontradiksi, konflik dan ketegangan terus menerus karena perbedaan dan pertentangan kepentingan (Kartodirdjo dan Djoko Suryo, 1991: 144).

xxii Hierarki kekuasaan dalam perusahaan perkebunan besar milik swasta asing memiliki struktur tersendiri sebagai sebuah organisasi besar dan modern, yang berdiri sendiri dan terpisah dari campur tangan pemerintah. Seperti yang diungkapkan Sartono kartodirdjo (Kartodirdjo dan Djoko Surjo, 1991: 147-148) bahwa perkebunan menjadi wilayah khusus sebagai enclave tersendiri, dapat dikatakan seperti negara dalam negara, lokasi secara administratif berada di dalam wilayah kekuasaan pemerintah daerah setempat, tetapi berkuasa penuh atas wilayah perkebunan dan perusahaannya.

xxiii Secara umum orang-orang yang menempati jabatan sinder afdeeling adalah yang memiliki keahlian di bidanganya (orang Eropa). Misalnya ahli tanaman menjadi sinder kebun, ahli mesin menjadi sinder pengolahan di pabrik dan atau sinder teknik, dan lain sebagainya (Nuralia, 2016: 37-38).

xxiv Gaya art deco mengedepankan bentuk geometris, elemen-elemen dekoratif horisontal dan vertikal, bentuk zig zag dan kerucut bertingkat-tingkat, serta bentuk simetris berulang. Banyak menggunakan list profil sebagai permainan dekorasi pada dinding.

xxv Gaya Art Nouveau/New Art: bahan kaca warna warni pada pintu-jendela (stained glass) atau kaca patri, hiasan pada dinding pintu-jendela berbentuk floral, sulur suluran, hati, motif bulu burung merak; pada langit-langit lekukan melingkar dan vertikal.

xxvi Gaya de stijl terutama memiliki dinding berbentuk kubus menyatu antara dinding luar dan dinding dalam, dan terkadang memiliki atap datar (teknik beton cor).

xxvii Gaya Amsterdam school menggunakan plesteran atau pahatan dekoratif yang menggunakan bahanbahan dari alam seperti batu bata, penggunakan ornament berbentuk seperti patung yang dipahat dengan keterampilan tangan. 